\title{
Measuring Education Inequality: Gini Coefficients of Education
}

\author{
Vinod Thomas, Yan Wang, and Xibo Fan*
}

December 15, 2000

\begin{abstract}
* Respectively, Vice President, senior economist, and consultant, at The World Bank Institute. This is an extension of our paper, "Measuring Educational Inequality: Education Gini Index from 1960 to 1990." mimeo, World Bank Institute. September 27, 1999. Washington D.C. The authors thank Ramón E. López for collaborating a paper on this topic using data from 20 countries, Nancy Birdsall, Shaohua Chen, Deon Filmer, Emmanuel Jimenz, Peter Moock, Martin Ravallion and The Quality of Growth team, for their comments and suggestions, and the Bank's Research Committee for providing a part of the funding. The findings, interpretations and conclusions expressed here are those of the authors. They do not necessarily represent the views of the World Bank, its Executive Directors or the countries they represent. Comments and questions should be sent to the corresponding authors, Yan Wang at ywang2@worldbank.org and/or Xibo Fan at gini@egroups.com. The dataset is available at the World Bank's web page http://www.worldbank.org/devforum/forum_qog3.html.
\end{abstract}




\title{
Measuring Education Inequality: Gini Coefficients of Education
}

\author{
Vinod Thomas, Yan Wang, and Xibo Fan
}

\begin{abstract}
Equal access to education is among the basic human rights and a component of well being. Yet, the educational gaps between various groups in many countries are staggering. This paper employs an education Gini index to measure inequality in educational attainment. It presents both the direct and indirect methods of calculating the education gini index, and generates a quinquennial dataset on education Gini for population age over fifteen, for 85 countries from 1960 to 1990. Preliminary empirical analysis finds that, first, education inequality for most of the countries has been declining during the three decades, with a few exceptions. Second, education inequality measured by education Gini is negatively associated with the average years of schooling. This implies that countries with a higher education attainment level are most likely to achieve better education equality than those with lower attainment levels. Third, a clear pattern of education Kuznets Curve exists if the standard deviation of education is used. Fourth, gender-gaps are clearly related to the education inequality, and over time, the impact of gender-gaps on inequality has become stronger. Fifth, per capita GDP (PPP) increments are negatively associated with education inequality, and they are positively related to the average years of schooling of the labor force, after controlling for initial income levels.
\end{abstract}

JEL Classification code: C43, D63, I32, J24, O11, O15 


\section{Introduction}

Equal access to education is among the basic human rights to which everyone is entitled. Yet, the educational gaps between various groups in many countries are staggering, as shown by many studies. If people's abilities are normally distributed, then a skewed distribution of education opportunities represents large welfare losses. As with land and machinery, an equitable distribution of human capital (basic literacy and nutrition/health) constitutes a precondition for individual productivity and ability to rise above poverty. ${ }^{1}$ Furthermore, equitable distribution of opportunities is preferable to a redistribution of existing assets or incomes. This is because education creates new assets and improves social welfare by its spill-over effect, without making anyone worse off. Ensuring access to the opportunity of education by distributing education services more equally, is a win-win policy gaining support in industrial and developing countries. To support such an effort, an indicator that can be easily calculated and monitored over time would be useful.

This paper aims at developing a measure for educational inequality, using the concept of education gini index based on school attainment data, for a large number of countries over time. Education gini could be used as one of the indicators of welfare, complementing average education attainment, health and nutrition, income per capita, and other indicators of welfare. After reviewing the literature and discussing the methodology, we look into the relationship between the education gini index and average education attainment, gender gaps, changes in income, and the standard deviation of education. As a narrowly focused technical paper, we do not attempt to find a casual relationship between inequality in education and growth, as they could be jointly determined and mutually reinforcing.

Standard deviations and Gini coefficients are often chosen as measures of inequality. Standard divisions of school attainment were used in a few studies. Only four previous studies were found to have used Gini coefficients in measuring education inequality. They estimated the Gini coefficient based on either enrollment or education finance. To properly measure education inequality, a gini index should be based on education attainment data. However, to our knowledge, no study has estimated education Gini coefficient based on education attainment for a large number of industrial and developing countries. (See table 1 for a selective literature review.)

\section{Indicators to Measure Various Aspects of Education}

Various indicators have been used to measure different aspects of education in cross country analyses. These indicators include, among others, enrollment ratios, education attainment, quality by input of resources, and quality by cognitive test scores. On the spread of education, standard deviation of years

\footnotetext{
${ }^{1}$ There was a heated debate over the "Equity of what?" Amartya Sen (1980) sees individual's levels of functionings, such as literacy and nutrition, as attributes to be equalized. Others see the opportunities people face as the attributes to be equalized (Arneson 1989, Cohen 1989, and Roemer 1993). Yet others consider the amount of resources as the attribute to be equalized (Dworkin 1981).
} 
of schooling was used, and lately, the education Gini index, as a new indicator to measure education inequality. This section briefly explains the usefulness of the various indicators that measure different aspects of education.

Flow variable: Enrollment Ratios. At the early stage, the enrollment ratios for different levels of schooling were used as indicators of human development (Barro 1991, Mankiw et al 1992, Levine and Renelt 1992, Levine and Zervos 1993). The most commonly used are the primary- and secondary enrollment ratios. One problem of this approach is that enrollment ratio only measures the flow of population's education or access to education. It does not show the cumulated education attainment/outcome. As a result, it is often inappropriate to use these enrollment ratios in growth models. Measuring education inequality based on enrollment data is also problematic as they do not reflect the stock of human capital.

Stock variable: Attainment measured by Number of Average Years of Schooling. Psacharopoulos and Arriagada (1986) suggested that the proper indicator of human development level is the stock of education attainment defined as average years of schooling. Psacharopoulos and Arriagada (1986) made the efforts of collecting the census information on each country's schooling distribution over the entire population, and calculated education attainment. Barro and Lee (1991, 1993, and 1997) gathered more data and formalized the use of education attainment for growth regressions. Nehru, Swanson, and Dubey (1994) also created a cross country database for education attainment, through estimating the schooling distributions over time for various countries. Measuring the spread of education based on these attainment data becomes feasible.

The Quality of Schooling. Education attainment across countries may not be comparable as the quality of schooling differ widely. Behrman and Birdsall (1983) and others (Lockheed and Verspoor 1991; Card and Krueger 1992) warned that quantity alone is not enough, quality must be taken into consideration when measuring the level of human development. Two typical approaches were used to measure the quality of education, the input approach and the output approach, each with its own problems and limitations.

The Input Approach (Resources for Schooling). One way to measure the education quality is to see which country devotes more resources to education than others. Resources being inputted into the education systems can be measured by pupil-teacher ratio, by expenditures on teachers' wage, by spending on book and reading materials. One problem is that high volume of input does not necessarily yield high quality. Another problem is that the inputs for schools are not independent of the income. There is limited feasibility of using inputs of schooling as proxies for education quality (Hanushek and Kim 1995).

The Output Approach (Test Score of Cognitive Performance). The output approach directly measures the achievements of schooling by comparing the scores of cognitive performance, which the students of the same-age group of various countries obtained through the same international tests on the same subjects including mathematics and science. The tests to assess student achievement in mathematics and science were conducted both by the International Association for Evaluation of 
Educational Achievement (IEA) and by international Assessment of Education progress (IEAP). ${ }^{2}$ Two problems that prevented these measures to be widely used include that first, they are only available for a dozen, mostly industrial, countries, and second, they are not comparable over time. It is for these reasons, we cannot use them to control for the quality of education in the education gini index that we constructed.

The Distribution of Education: why important. The distributional dimension of education is extremely important for both welfare consideration and for production. If an asset, say physical capital, is freely traded across firms in a competitive environment, its marginal product will be equalized through free-market mechanism. As a result, its contribution to output will not be affected by its distribution across firms or individuals. If an asset is not completely tradable, however, then the marginal product of the asset across individuals is not equalized, and there is an aggregation problem. In this case, aggregate production function depends not only on the average level of the asset but also on its distribution. Because education/skill is only partially tradable, the average level of education attainment alone is not sufficient to reflect the characteristics of a country's human capital. We need to look beyond averages and investigate both the absolute dispersion and the relative dispersion of human capital.

Standard Deviation of Schooling: Absolute Dispersion. There is a small but growing literature on schooling inequality or the distribution of education (see, for example, Lam and Levinson 1991; Londoño 1990; Ram 1990). As data became available for measuring the distribution of education, the disparities became more apparent. Standard deviations have been used often to measure the absolute dispersion distribution of assets. Birdsall and Londono (1997), investigating the impact of initial asset distribution on growth and poverty reduction, found a significant negative correlation between education dispersion (measured by the standard deviation of schooling) and income growth. In the Inter-American Development Bank (1999) study on inequality in Latin America, the standard deviation of schooling is used to measure inequality of education, and it was found that the larger the standard deviation of schooling, the greater the income inequality--measured by income Gini. (See Table 1 for literature review). Rati Ram used the standard deviations of schooling to illustrate the existence of an education Kuznuts curve, and concluded that, "As the average level of schooling rises, educational inequality first increases, and after reaching a peak, starts to decline. The turning point is about seven years of education" (Ram 1990). Londoño 1990 also used the same method.

\footnotetext{
${ }^{2}$ Hanushek and Kim (1995) first transformed the test scores into unified scales, and then utilized the index to test how much of the growth was affected by both the quantity and the quality of education. They found that both the quantity and the quality of schooling positively contribute to the growth of income, at statistically significant levels. The output approach measures the quality of education based on student cognitive performance, which was regarded by Hanushek and Kim (1995) as a complement to the quantity of education developed by Barro and Lee (1993). Lee and Barro (1997) investigated the determinants of school quality, and found that greater school inputs, longer school terms, family background, and strong communities are positively related to student performance. However, they cannot fully explain the better education outcomes in East Asian countries than in other developing countries. It suggests other factors at play, including those associated with a more open and export-oriented economic environment.
} 
Education Gini: Measurement of Relative Inequality. Standard deviation of schooling only measures the dispersion of schooling distribution in absolute terms. To measure the relative inequality of schooling distribution, developing an indicator for education Gini is necessary. ${ }^{3}$

Four previous studies were found to have used Gini coefficient in measuring the inequality of education. Education Gini, which are similar to the Gini coefficients widely used to measure distributions of income, wealth, and land, ranges from 0 , which represents perfect equality, to 1 , which represents perfect inequality. Education Gini coefficients can be calculated using enrollment, financing, or attainment data. Maas and Criel (1982) estimated Gini coefficients based on enrollment data for 16 East African countries. First, they found that the degree of inequality in education opportunity varied enormously from one country to another. Second, enrollment Gini coefficients were negatively related with the average enrollment rate in a country. In other words, the higher the average enrollment, the lower the inequality. This is consistent with what we found on average education attainment and education inequality using a different method. Ter Weele (1975) estimated Gini coefficients using education finance data for several East African countries. Rosthal (1978) summarized four indicators for the distribution of education estimated for the United States and Gini index was one of them. Sheret (1982 and 1988) estimated the Gini coefficient of enrollment for Papua New Guinea. However, the above-mentioned Ginis were calculated based on enrollment or education financing, not on the distribution of school attainment.

In this paper, we calculate an education Gini index that is based on education attainment of the concerned population (or labor force). Thanks to the painstaking efforts made by a group of pioneers including Barro and Lee (1991, 1993, and 1997), Psacharopoulos and Arriagada (1986), and Nehru, Swanson and Dubey (1995), the data is now available on proportions of population with various level of education attainment for major developing and industrial countries. Lopez, Thomas and Wang (1998) were among the first to try Gini coefficients of education for 12 countries, by utilizing the education attainment data. The dataset was then updated/revised and expanded to 20 countries in a later version (May 1999). In this paper, education gini indexes are calculated for 85 countries for the period from 1960-1990, using a consistent method which is discussed below.

\footnotetext{
${ }^{3}$ Both the income Gini and the wealth Gini coefficients have been widely used in studies of growth, poverty and inequality. For example, Deininger and Squire (1996) constructed a new data set on inequality in the distribution of income. They found a systematic link between growth and changes in aggregate inequality, and a strong positive relationship between growth and reduction of poverty. Li, Squire, and Zou (1998) tried to explain income inequality mainly by three variables: financial depth, civil liberty, and land ownership inequality (land Gini). They found that higher concentration of land contributed to higher income inequality. On the other hand, after adding a dummy variable for the region of Latin America, the Inter-American Development Bank (1999) de-emphasized the significance of land concentration with respect to income inequality. Lundberg, and Squire (1999) utilized twenty variables of 120 countries, tested various specifications both for poverty and for growth, and come out with two strong conclusions. First, growth is much more sensitive to policy intervention than to inequality is. Second, even a moderate change in inequality coupled certain growth is of tremendous impact on alleviating poverty.
} 


\section{Education Gini: Concept and Methodology}

Starting with income gini coefficient, there are two ways to calculate an income Gini, the direct method (Deaton 1997) and the indirect method. Mathematically, the direct method states that the income Gini is defined as "the ratio to the mean of half of the average over all pairs of the absolute deviations between [all possible pairs of] people" (Deaton 1997). The indirect method first constructs the income Lorenz curve, with the cumulative percentage of the income on the vertical axis, and the cumulative percentage of the population on the horizontal axis. The forty-five degree line is called the egalitarian line for it represents a completely equal society with respect to the distribution of income. And then the Gini coefficient is calculated as the ratio of two areas, with the area of the egalitarian triangle as the denominator and the area between Lorenz curve and the egalitarian line as the numerator. The geometric representation of the income Gini definition is shown in Figure 1.

Similarly, both the direct method and the indirect method can also applied to the education Gini. As an analogue to Deaton's definition, education Gini measures the ratio to the mean (average years of schooling) of half of the average schooling deviations between all possible pairs of people. The mathematical representation of this definition is shown in Equation (1). ${ }^{4}$

\subsection{The Direct Method for Calculating Gini Coefficient}

The direct method uses the following formula to calculate Gini coefficient (Deaton 1997).

$$
G I N I=\frac{1}{\mu N(N-1)} \sum_{i>j} \sum_{j}\left|y_{i}-y_{j}\right|
$$

Where,

GINI is the Gini index;

$\mu$ is the mean of the variable (income, e.g.);

$\mathrm{N}$ is the total number of observations;

For income Gini, $y_{i}$ and $y_{j}$ are dollar values of income of individuals;

For education Gini, $y_{i}$ and $y_{j}$ are years of school attainment of individuals.

\subsection{The Indirect Method through the Construction of Lorenz Curve}

The indirect method first constructs the education Lorenz curve, with the cumulative percentage of the schooling years on the vertical axis, and the cumulative percentage of the population on the horizontal axis. The forty-five degree line is the education egalitarian line for it represents a completely equality of

\footnotetext{
${ }^{4}$ To promote usage by noneconomists, this section does not require any prior knowledge on gini coefficient.
} 
schooling. The Gini coefficient is defined as the ratio of the area formed by the Lorenz curve and the egalitarian line to the area of the entire egalitarian triangle (see Figure 1).

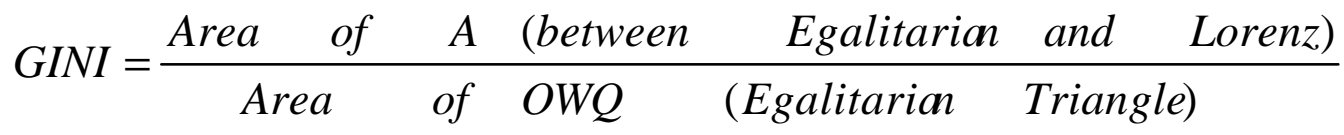

Figure 1. The Lorenz Curve and Income Gini

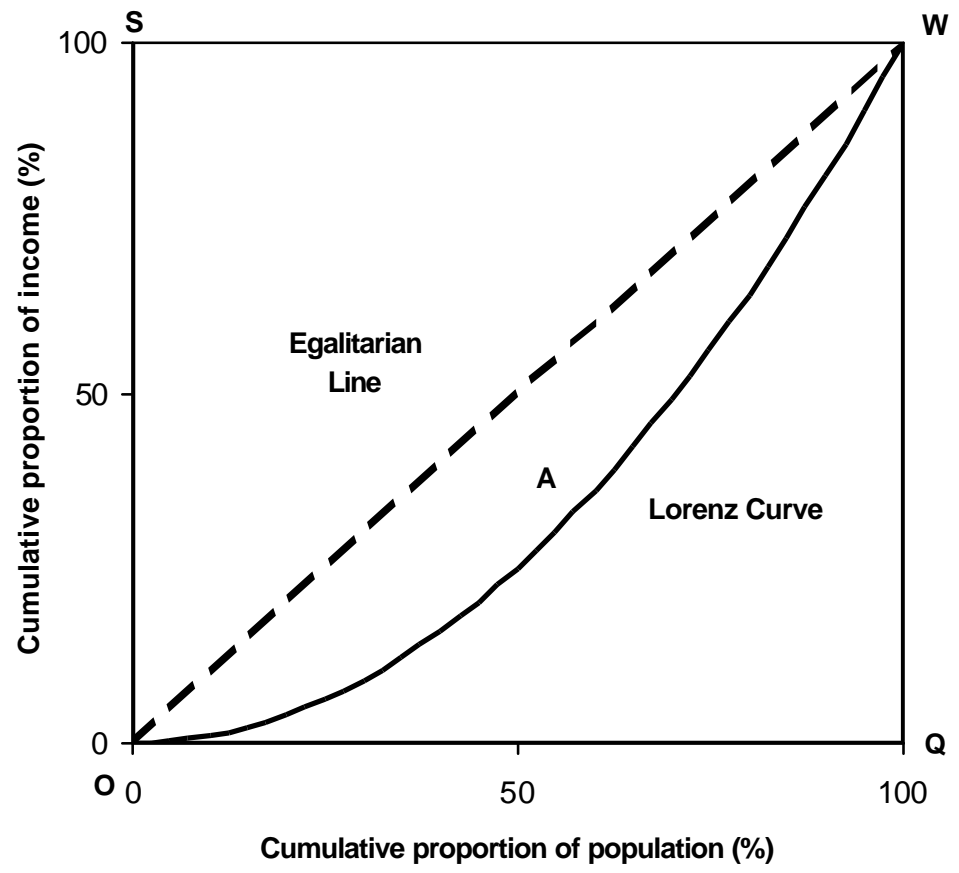

\subsection{Limitations of Traditional Methods}

The distribution of schooling has several special characteristics. Even though the concept of education Gini is the same as the income Gini, several obstacles have prevented us from applying the conventional income Gini methods for calculating education Gini.

(1) First, household / individual surveys on education attainment are not available for many countries, which implies that that the equation (1) cannot be directly applied for the calculation of education Gini. ${ }^{5}$ Barro and Lee (1991) divided the population into 7 categories, no-schooling

\footnotetext{
${ }^{5}$ If the objective is to calculate education gini for one or a few countries, equation 1 can be used on household survey data.
} 
(or illiterate), partial primary, complete primary, partial secondary, complete secondary, partial tertiary, and complete tertiary. The seven groups are both mutually exclusive and collectively inclusive. To accommodate the special feature of this education attainment data, a new formula has to be worked out from the Gini definition of Equation (1).

(2) Second, the education attainment in years of schooling is a discrete variable, not a continuous variable, whereas income is a continuous variable. Usually, a country's income distribution is standardized into quintiles or deciles. The World Bank's Development Research Group developed a software for calculating income Gini, by way of estimating a continuous Lorenz curve function based on a country's scattered income distribution. However, the levels of schooling are discrete variables and they have both a lower boundary (zero) and an upper boundary (around 15 to 20 years). As a result, the education Lorenz curve is a kinked line with seven kink points. It is not necessary to estimate a continuous curve to approximate the education Lorenz Curve.

(3) Third, the education Lorenz Curve is truncated along the horizontal axis (Figures 2, 4, 5). In many developing countries a big proportion of population is illiterate (schooling=0), as shown in the education Lorenz curves for India in Figure 4. The software package developed by the World Bank's Development Research Group for calculating Gini cannot be used due to the truncation problem at the horizontal axis (schooling=0). We have to develop our unique formula to accommodate the special features of the schooling distribution data. ${ }^{6}$

\subsection{The First Formula for Calculating Education Gini}

The education Gini formula used in this paper is shown in equation (3).

$$
E_{L}=\left(\frac{1}{\mu}\right) \sum_{i=2}^{n} \sum_{j=1}^{i-1} p_{i}\left|y_{i}-y_{j}\right| p_{j}
$$

Where,

$E_{L}$ is the education Gini based on education attainment distribution, large population;

$\mu$ is the average years of schooling for the concerned population;

$\mathrm{p}_{\mathrm{i}}$ and $\mathrm{p}_{\mathrm{j}}$ stand for the proportions of population with certain levels of schooling;

$y_{i}$ and $y_{j}$ are the years of schooling at different education attainment levels;

$\mathrm{n}$ is the number of levels/categories in attainment data, and $\mathrm{n}=7$ in this paper. Barro and Lee (1991) divided the population into seven categories including no-schooling (or illiterate), partial primary, complete primary, partial secondary, complete secondary, partial tertiary, and complete tertiary. The seven groups are both mutually exclusive and collectively inclusive for the concerned population.

\footnotetext{
${ }^{6}$ We thank Shaohua Chen at Development Research Group of the World Bank, for sharing their Gini software with us. Due to the truncation problem at the horizontal axis (when years of schooling=0), the computer program frequently runs into "overflow". So we had to develop our own formula.
} 
Expanding equation (3) gets the detailed summation process of the first education Gini formula, shown in equation (4). ${ }^{7}$

\section{(4) $E_{L}$}

$$
\begin{aligned}
=(1 / \mu) & {\left[p_{2}\left(y_{2}-y_{1}\right) p_{1}\right.} \\
& +p_{3}\left(y_{3}-y_{1}\right) p_{1}+p_{3}\left(y_{3}-y_{2}\right) p_{2} \\
& +\ldots \ldots \\
& \left.+p_{7}\left(y_{7}-y_{1}\right) p_{1}+p_{7}\left(y_{7}-y_{2}\right) p_{2}+p_{7}\left(y_{7}-y_{3}\right) p_{3}+p_{7}\left(y_{7}-y_{4}\right) p_{4}+p_{7}\left(y_{7}-y_{5}\right) p_{5}+p_{7}\left(y_{7}-y_{6}\right) p_{6}\right]
\end{aligned}
$$

Where,

$\mathrm{p}_{1}$ is the proportion of population with no schooling,

$\mathrm{p}_{2}$ is the proportion of population with partial primary education;

$\mathrm{p}_{7}$ is the proportion of population with complete tertiary education.

$\mathrm{y}_{1}$ is years of schooling for an individual with no schooling, $\mathrm{y}_{1}=0$;

$\mathrm{y}_{2}$ is years of schooling for an individual with partial primary education;

$\mathrm{y}_{7}$ is years of schooling for an individual with complete tertiary education.

The formula for calculating the years of schooling at the seven levels of education:

$$
\begin{aligned}
& \text { Illiterate: } \quad \mathrm{y}_{1}=0 \\
& \text { Partial-Primary: } \quad \mathrm{y}_{2}=\mathrm{y}_{1}+0.5 \mathrm{C}_{\mathrm{p}}=0.5 \mathrm{C}_{\mathrm{p}} \\
& \text { Complete-Primary: } \quad \mathrm{y}_{3}=\mathrm{y}_{1}+\mathrm{C}_{\mathrm{p}}=\mathrm{C}_{\mathrm{p}} \\
& \text { Partial-Secondary: } \mathrm{y}_{4}=\mathrm{y}_{3}+0.5 \mathrm{C}_{\mathrm{s}}=\mathrm{C}_{\mathrm{p}}+0.5 \mathrm{C}_{\mathrm{s}} \\
& \text { Complete-Secondary: } \mathrm{y}_{5}=\mathrm{y}_{3}+\mathrm{C}_{\mathrm{s}}=\mathrm{C}_{\mathrm{p}}+\mathrm{C}_{\mathrm{s}} \\
& \text { Partial-Tertiary: } \quad \mathrm{y}_{6}=\mathrm{y}_{5}+0.5 \mathrm{C}_{\mathrm{t}}=\mathrm{C}_{\mathrm{p}}+\mathrm{C}_{\mathrm{s}}+0.5 \mathrm{C}_{\mathrm{t}} \\
& \text { Complete-Tertiary: } \quad \mathrm{y}_{7}=\mathrm{y}_{5}+\mathrm{C}_{\mathrm{t}}=\mathrm{C}_{\mathrm{p}}+\mathrm{C}_{\mathrm{s}}+\mathrm{C}_{\mathrm{t}}
\end{aligned}
$$

Where,

$\mathrm{C}_{\mathrm{p}}$ is the cycle of the primary education;

$\mathrm{C}_{\mathrm{s}}$ is the cycle of the secondary education; and

$\mathrm{C}_{t}$ is the cycle of the tertiary education.

The data on cycles of schooling $\left(\mathrm{C}_{\mathrm{p}}, \mathrm{C}_{\mathrm{s}}, \mathrm{C}_{\mathrm{t}}\right)$ is obtained from Psacharopoulos and Arriagada (1986). People who receive partial education is assumed to get half of the schooling cycle in their years of schooling, shown in equation (5.2), (5.4), and (5.6).

\footnotetext{
${ }^{7}$ For the underlying assumptions and the detailed logic of the methodology, please refer to the sister paper "The Formula for Calculating Education Gini Index" (Xibo Fan 2000).
} 


\subsection{The Second Formula for Calculating Education Gini}

The value of Gini is sensitive to population size $\mathrm{N}$ if the population size is too small. The sensitivity is reflected by a factor of [N/(N-1)]. The education Gini formula for a small population is shown in equation (6).

$$
E=\left(\frac{N}{N-1}\right) *\left[\left(\frac{1}{\mu}\right) \sum_{i=2}^{n} \sum_{j=1}^{i-1} p_{i}\left|y_{i}-y_{j}\right| p_{j}\right]=\left(\frac{N}{N-1}\right) * E_{L}
$$

Where,

$E$ is the education Gini based on education attainment distribution;

$\mathrm{N}$ is the number of individuals in the concerned population.

Multiplying equation (4) with a factor of [N/(N-1)] gives us the detailed summation process for the second education Gini formula of equation (6).

Theoretically, when population size $\mathrm{N}$ approaches infinite, $[\mathrm{N} /(\mathrm{N}-1)]=1$, and the second formula becomes the first formula. Practically, when population size is large enough, the first formula is good enough to achieve a high level of accuracy. The beauty of the first formula is that the exact number of the population size is irrelevant to the value of Gini as long as we know the concerned country has a large population.

The average years of schooling (AYS) can be calculated as follows.

$$
\mu=A Y S=\sum_{i=1}^{n} p_{i} y_{i}
$$

We also calculated the standard deviation of schooling (SDS) by using formula (8).

$$
\sigma=S D S=\sqrt{\sum_{i=1}^{n} p_{i}\left(y_{i}-\mu\right)^{2}}
$$

\subsection{The Education Lorenz Curve}

The education Lorenz curve in Figure 2 is constructed by putting the cumulative proportion of population on the horizontal axis, and by putting the cumulative proportion of schooling on vertical axis. The cumulative proportion of population at each level is as the following. 
(9.1) Illiterate:

$\mathrm{Q}_{1}=\mathrm{p}_{1}$

(9.2) Partial-Primary:

$\mathrm{Q}_{2}=\mathrm{p}_{1}+\mathrm{p}_{2}$

(9.3) Complete-Primary: $\mathrm{Q}_{3}=\mathrm{p}_{1}+\mathrm{p}_{2}+\mathrm{p}_{3}$

(9.7) Complete-Tertiary: $\mathrm{Q}_{7}=\mathrm{p}_{1}+\mathrm{p}_{2}+\mathrm{p}_{3}+\mathrm{p}_{4}+\mathrm{p}_{5}+\mathrm{p}_{6}+\mathrm{p}_{7}=100 \%$

The cumulative proportion of schooling at each level of schooling is as follows.

(10.1) Illiterate:

$$
\begin{aligned}
& S_{1}=\left(p_{1} y_{1}\right) / \mu=0 \\
& S_{2}=\left(p_{1} y_{1}+p_{2} y_{2}\right) / \mu \\
& S_{3}=\left(p_{1} y_{1}+p_{2} y_{2}+p_{3} y_{3}\right) / \mu
\end{aligned}
$$

(10.2) Partial-Primary:

(10.3) Complete-Primary

(10.7) Complete-Tertiary: $\quad S_{7}=\left(p_{1} y_{1}+p_{2} y_{2}+p_{3} y_{3}+p_{4} y_{4}+p_{5} y_{5}+p_{6} y_{6}+p_{7} y_{7}\right) / \mu$

$$
=\mu / \mu=100 \%
$$

Figure 2. The Education Lorenz Curve

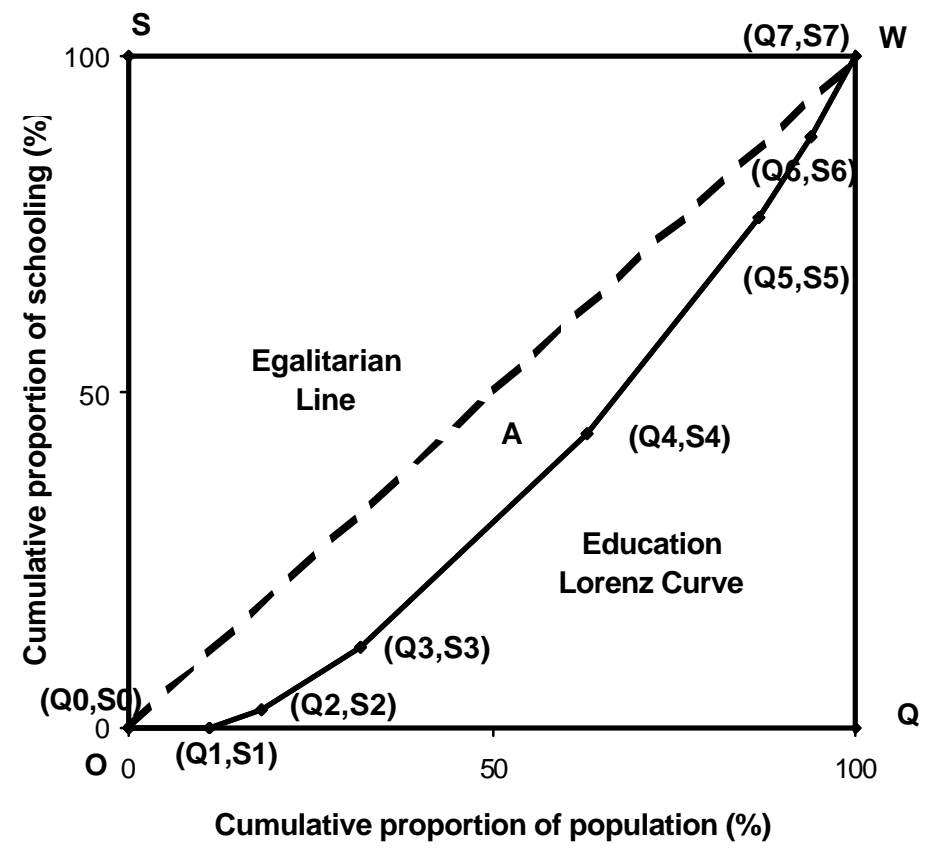

After constructing the education Lorenz curve, the calculation of education gini is straightforward based on equation (2). This is the indirect method without using equations (3) and (6). 


\section{Education Gini: Stylized Facts and Empirical Results}

We generated the education Gini dataset by utilizing both the schooling distribution data of Barro and Lee (1991, 1993, and 1997) and the schooling cycle data of Psacharopoulos and Arriagada (1986). The quinquennial dataset contains education Gini for 85 countries, for the population aged over fifteen, within the time span from 1960 to 1990. In addition to the data on education Gini, we also calculated the average years of schooling and the standard deviations of schooling, for the same number of countries and years. In this section, we investigate the behavior of these variables over time and the relationships among some of them. We made the following observations.

- Inequality in education attainment for most of the countries had been declining during the three decades of 1960-1990, with a few exceptions.

- There is a negative relation between the education Gini index and the average years of schooling. This implies that countries with a higher education attainment level are most likely to achieve better education equality than those with lower attainment levels.

- An educational Kuznets Curve exists if the standard deviation of education is used.

- Gender-gaps were clearly related to the education inequality, and over time, the impact of gendergaps on inequality has become stronger.

- It is found that education inequality is negatively associated with per capita GDP increments in PPP terms, and that education attainment in years of schooling is positively associated with the per capita GDP (PPP) increments, after controlling for initial income levels.

\subsection{The Historical Trends of Education Inequality Measured by Education Gini}

Education Gini indexes allow us to observe how education inequality in various countries have changed overtime during the period of 1960 to 1990 (Figure 3). The first stylized fact is that the education inequality measured by education Gini has been declining, albeit slowly, for most of the countries. Whereas they were worsened only in a small number of countries during certain periods. From 1960 to 1990, education Ginis were declining rapidly in some countries, such as Korea, Tunisia, and China, but slowly in other cases such as India, Mali, Pakistan.

Korea had the fastest expansion in education coverage and the fastest decline in the education Gini coefficient; it dropped from 0.55 to 0.22 in 30 years. Tunisia also had a rapid improvement in the distribution of education, with gini index declined from 0.94 in 1960 to 0.61 in 1990. India's education Gini coefficient declined moderately, from 0.79 in 1960 to 0.69 in 1990. Education Gini coefficients for Colombia, Hungary, Peru, and Venezuela have been increasing slowly since the 1980s, showing that inequality is on the rise (see Figure 3). 
Figure 3. Historical Trends of Education Gini, Selected Countries

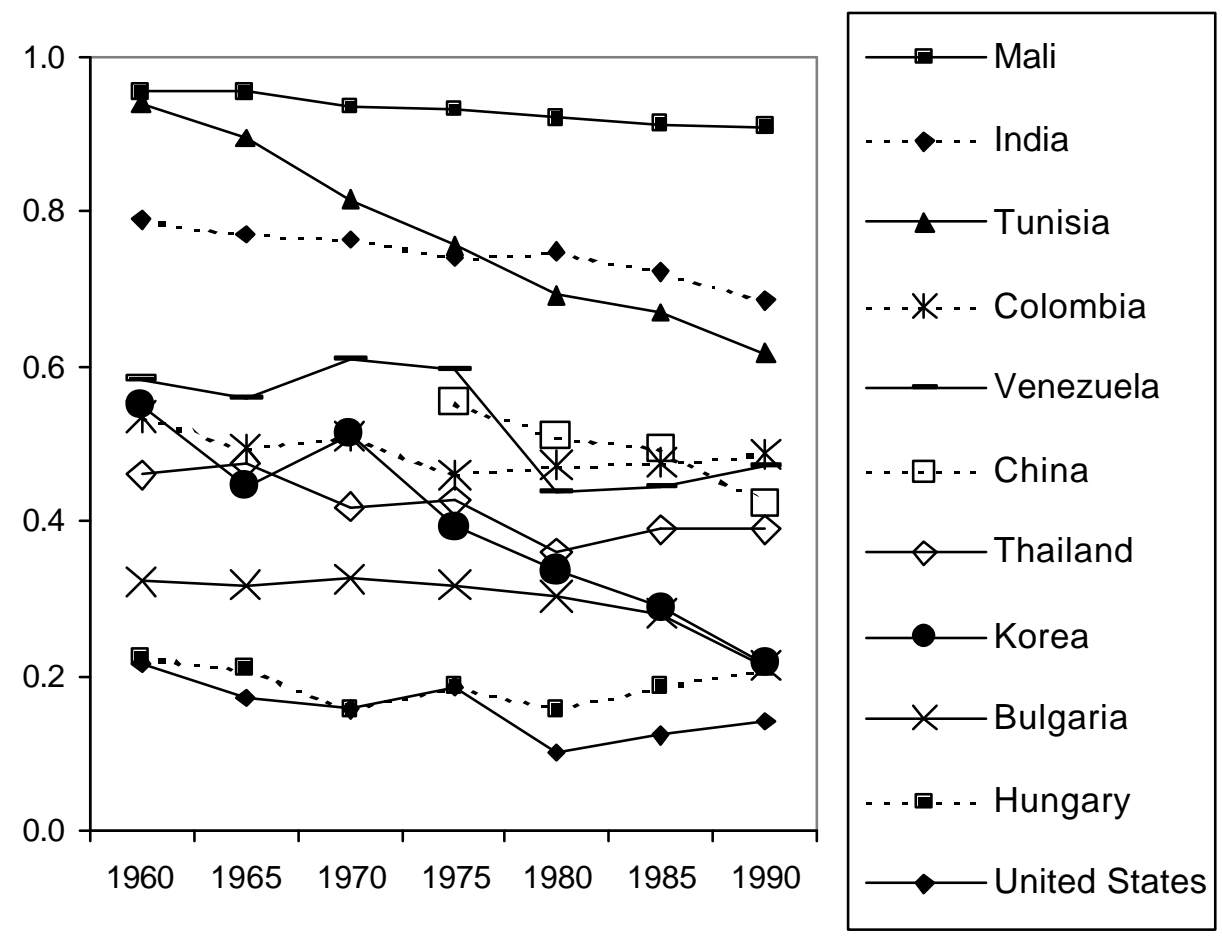

Source of data: Authors' calculation. Data available on the web and upon request.

\subsection{Education Lorenz Curves of India and Korea}

The improvement of education equality can be shown by the shifting of a country's education Lorenz curve. An examination of education Lorenz curves for India and Korea in 1990 shows a great range among developing countries.

The Case of India. Despite progress in expanding primary and secondary enrollment in India, more than half of the population (age 15 and older) did not receive any education while 10 percent of the population received nearly 40 percent of total cumulated years of schooling. This made its education Lorenz Curve steep, located far away from the egalitarian line, leading to a large education Gini (Figure 4). Education gini being among one of the highest in the world, providing universal access to basic education remains a huge challenge for the country.

A distribution of education as skewed as that of India implies a huge social loss from the underutilization of potential human capital. Assuming that ability or talent is normally distributed across population groups, production increases to its optimum when the dispersion of education matches the 
distribution of human ability. When the distribution of education is too skewed to match the distribution of ability, there is a deadweight loss to the society of underdeveloped and underutilized talent. In this case, societies would be better off to massively expand basic education, especially by improving access to education for the poor.

Figure 4. Education Lorenz Curves, India, 1960 and 1990
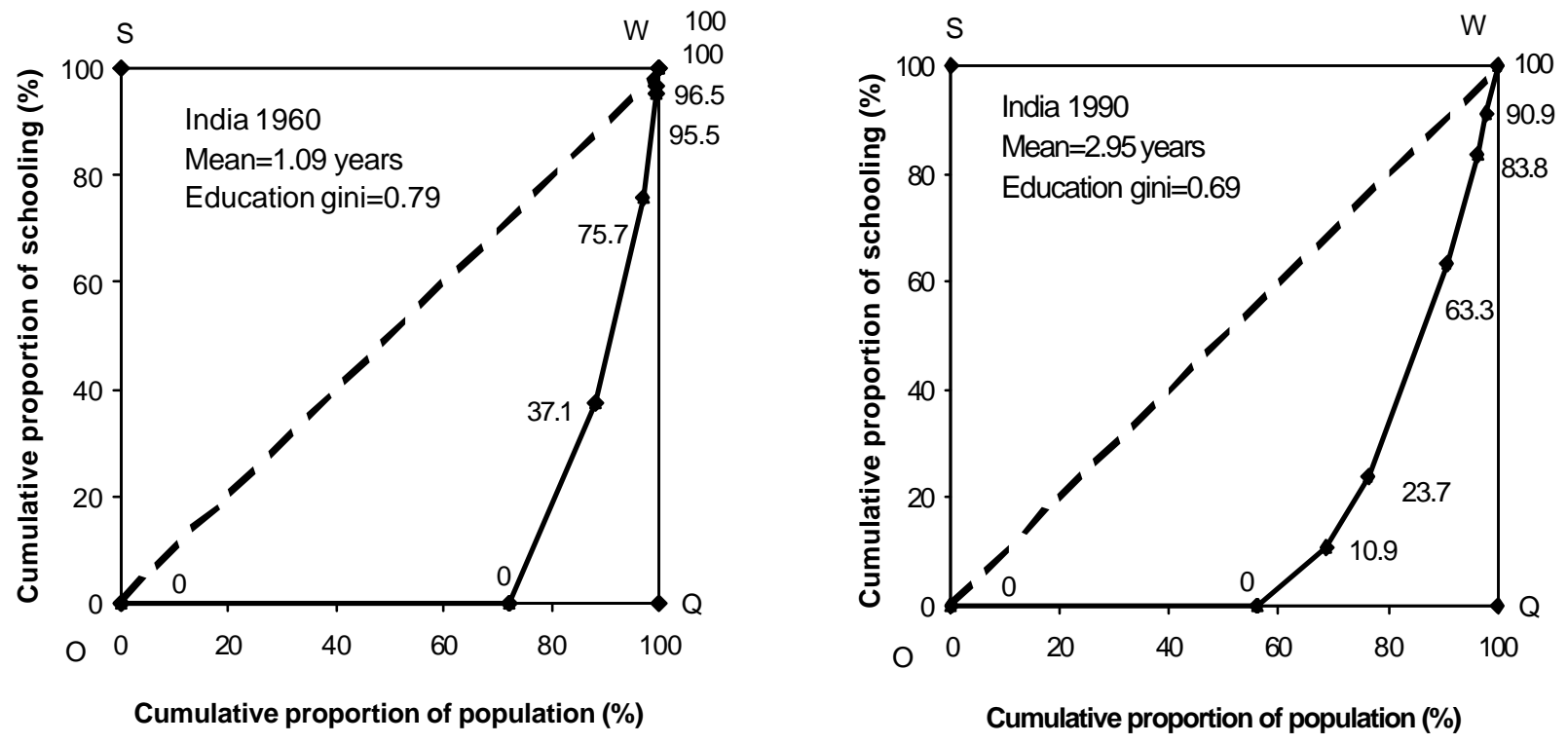

Source: Authors' calculation.

The Case of Korea. Korea expanded its basic education rapidly and eliminated illiteracy successfully. In the early 1960s and 70s, over two thirds of government expenditure on education were concentrated on primary and secondary schooling. Over the three decades from 1960 to 1990, the mean years of schooling doubled and a large proportion of the population became literate. Comparing to other countries, Korea's education Lorenz curve have shifted much closer toward the forty-five degree egalitarian line.

In the 1990s, Korea enjoyed a more equitable distribution of education than India, as indicated by a flatter Lorenz curve and a smaller Gini coefficient. Even in 1960, when Korea's per capita income was similar to that of India, Korea's education Gini coefficient was 0.55 , much lower than that of India in 1990. Note that the distribution of education in Korea was more equitable than that of income, but the distribution of education in India was much more skewed than that of income between 1970 and 1990. 
Figure 5 Education Lorenz Curves, Korea, 1960 and 1990
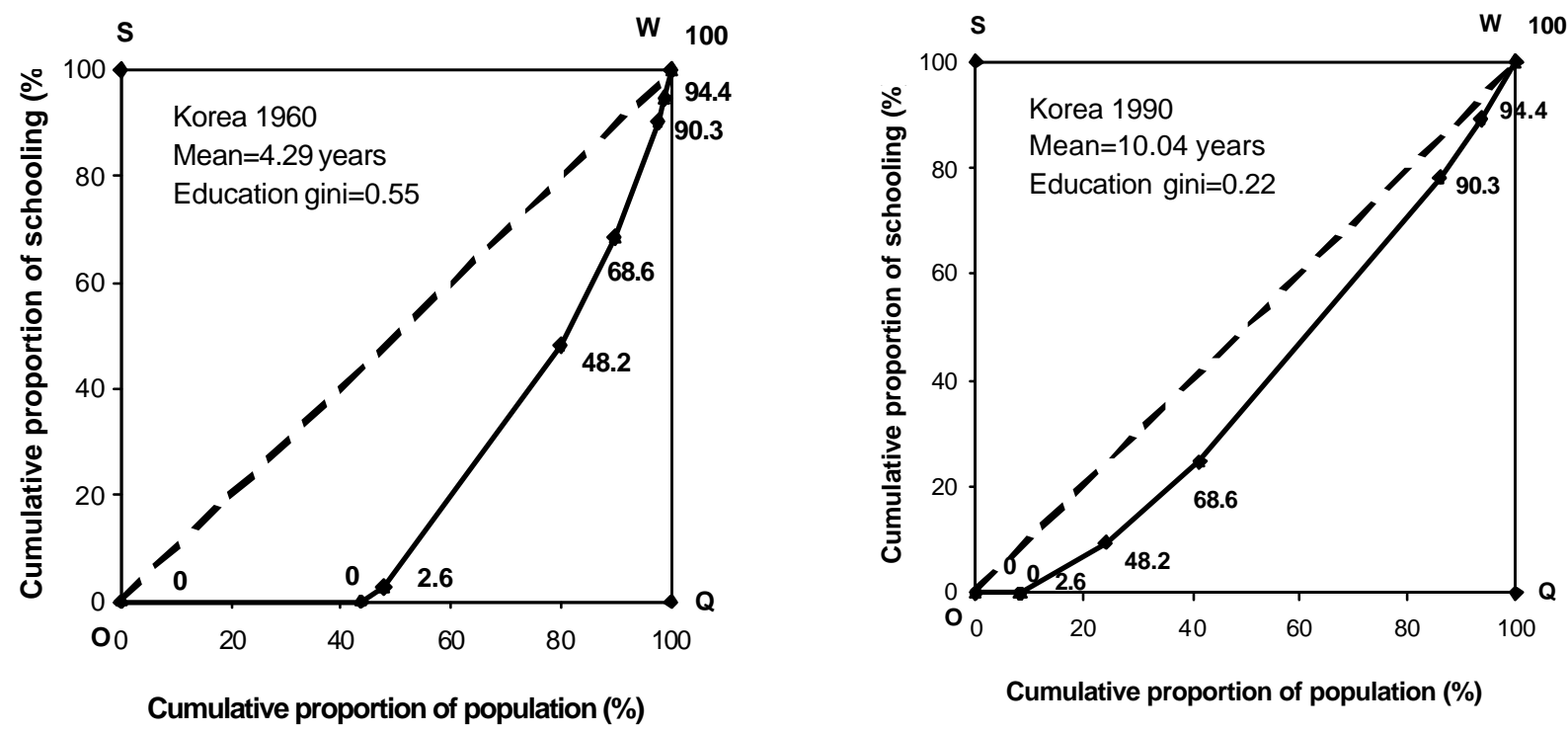

Source data: Authors' calculation.

\subsection{The Historical Trends of School Attainment}

The data on the number of average years of schooling also shows improvement of education attainment. The average years of schooling had been increasing for most of the countries. However, Afghanistan was one of countries that had the lowest school attainment. And even worse, its schooling attainment was still on the path of declining (See Figure 6).

Figure 6. Historical Trends of School Attainment for Population age 15 and over

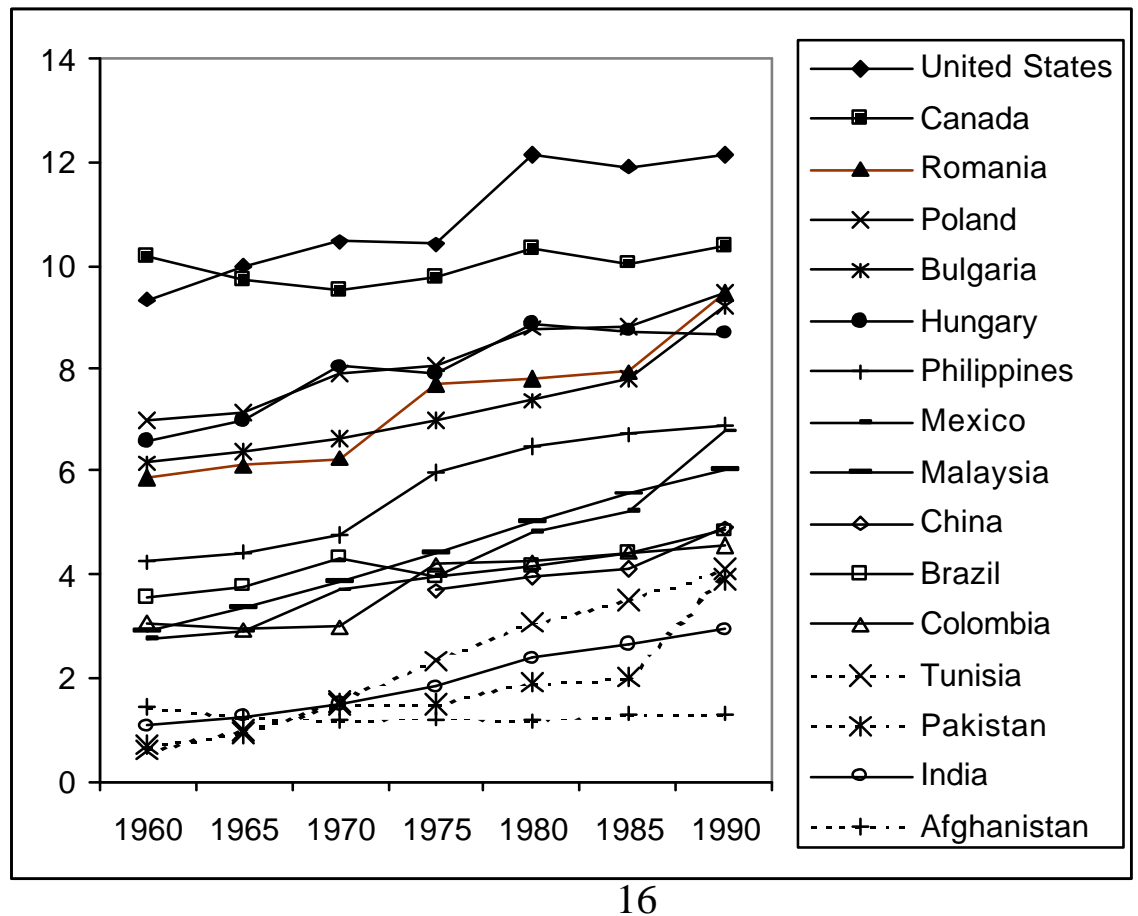


Source: Authors' calculation.

\subsection{International Comparison of Education Inequality}

Examining the cross-country pattern of the distribution of education, we found that education Gini coefficients decline as the average education levels increase, although there clearly are other possibilities (next section). In addition to the industrial countries, Argentina, Chile, and Ireland had relatively low education Gini coefficients throughout the whole period from 1960 to 1990 . The Gini coefficient for education in Korea, Tunisia and some other countries declined dramatically. Only a few countriesColombia, Costa Rica, Peru, and Venezuela — have seen a significant worsening of the education Gini coefficient. Among 85 countries for which education Gini coefficients were calculated, Afghanistan and Mali had the least equitable distributions in the 1990s at approximately 0.90, while most industrial countries were at the lower end, with the United States and Poland having the most equitable distribution (Figure 7).

Figure 7. Education Gini and Average Attainment in 1990

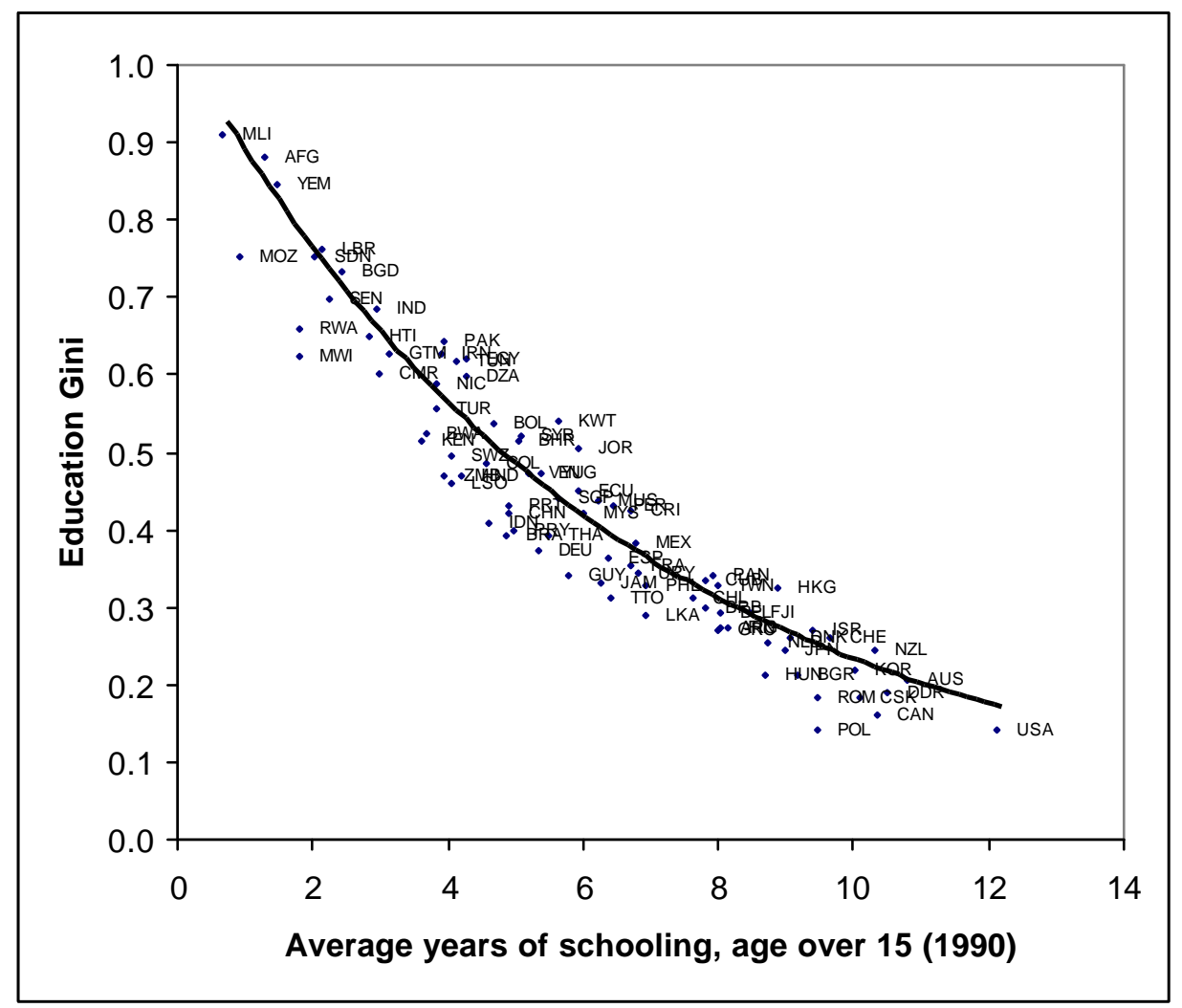

Source of data: Authors' calculation. 
This implies that the countries with a higher average years of schooling were most likely to achieve a more equitable education than those with a lower average years of schooling. It can also be found that the education inequality in low-income countries is most likely to be worse than that of high-income countries, measured by education Gini. The inverse relationship between the education Gini (education inequality) and the mean years of schooling (education attainment) is so robust that we found this pattern in every cross section from 1960 to 1990.

The panel data regression results in Table 4.1 also show a statistically significant evidence for this negative association between education attainment and education gini. The relationship is robust no matter whether we use fixed effect or random effect models, or whether we control for time-specific (column 1, fixed effect) or country-specific factors (column 2 and 3). By using fixed effect model, we have controlled for country-specific left-out variables such as initial income, thus controlling for heterogeneity.

Furthermore, this result has a strong policy implication. Moving any person out of illiteracy improves the society's education gini index and at the same time increase the country's level of education attainment. As we can see below, this is one of the advantage of using education gini, not the standard deviation, as a measure of inequality.

\subsection{Education Kuznets Curve}

Does the distribution of education have to get worse before it gets better? As suggested by Londoño (1990) and Ram (1990), there is a "Kuznetsian tale" with distribution of education. That is, as a country moves from the zero to maximum level of education, the variance first increases and then declines. However, we cannot find this Kuznets curve if education gini coefficients are used to measure inequality.

Using the standard deviation of education, a clear pattern of education Kuznets Curve exists, being shown in a scatter diagram below and by panel regressions. Figure 8 shows the 1990 education Kuznets Curve illustrated by cross-country data. As the average number of years of schooling increases, the standard deviations of schooling first rise, reaching a peak at around 6-7 years of schooling, and then decline. (See Figure 8). This observation is fairly consistent with what was observed by Ram (1990). We have observed seven similar education Kuznets curves, one each for the five-year intervals from 1960 to 1990.

When running panel regressions, both the fixed effect and the common effect models confirm the existence of an inverted U-shape education Kuznets Curve. This is shown in Table 4.2, by the positive coefficient on the mean year of schooling, and the negative coefficient for the mean-year-of-schooling squared, both significant. (Table 4.2). This relationship is robust no matter whether we run fixed effect or random effect method, or whether we control for time-specific or country-specific factors (column 2 and 3). 
Figure 8. Education Kuznets Curve, Standard Deviation of Schooling, 1990

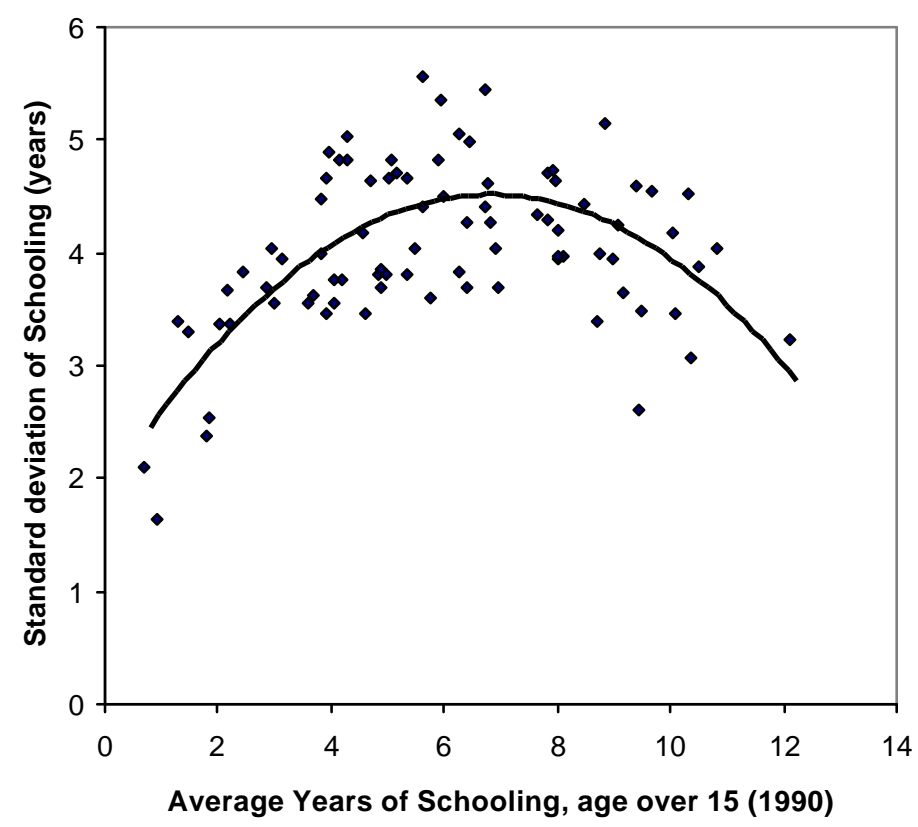

Source of data: Authors' calculation.

\subsection{The Historical Trends of Standard Deviation of Schooling}

Over time, we found no clear pattern for the sandard deviations of schooling within the time horizon of 1960 - 1990. The standard deviations were rising for most of the 85 countries, and declining for the others (See Figure 9).

The standard deviations of schooling for India, Tunisia and several others rose drastically over time, showing a widening spread of education attainment. For Thailand it was a "U"- shaped curve, declining first and rising later. For Korea it was an inverted "U"-shape, rising first and declining later. It was declining continuously for Canada, Romania, and Poland.

Intuitively, the standard deviation of schooling seems to be a more volatile, and sometimes misleading, indicator. It does not provide a consistent picture of whether the distribution of education in a country is improving or not. 


\section{Figure 9 Time Trends for Standard Deviations of Schooling}

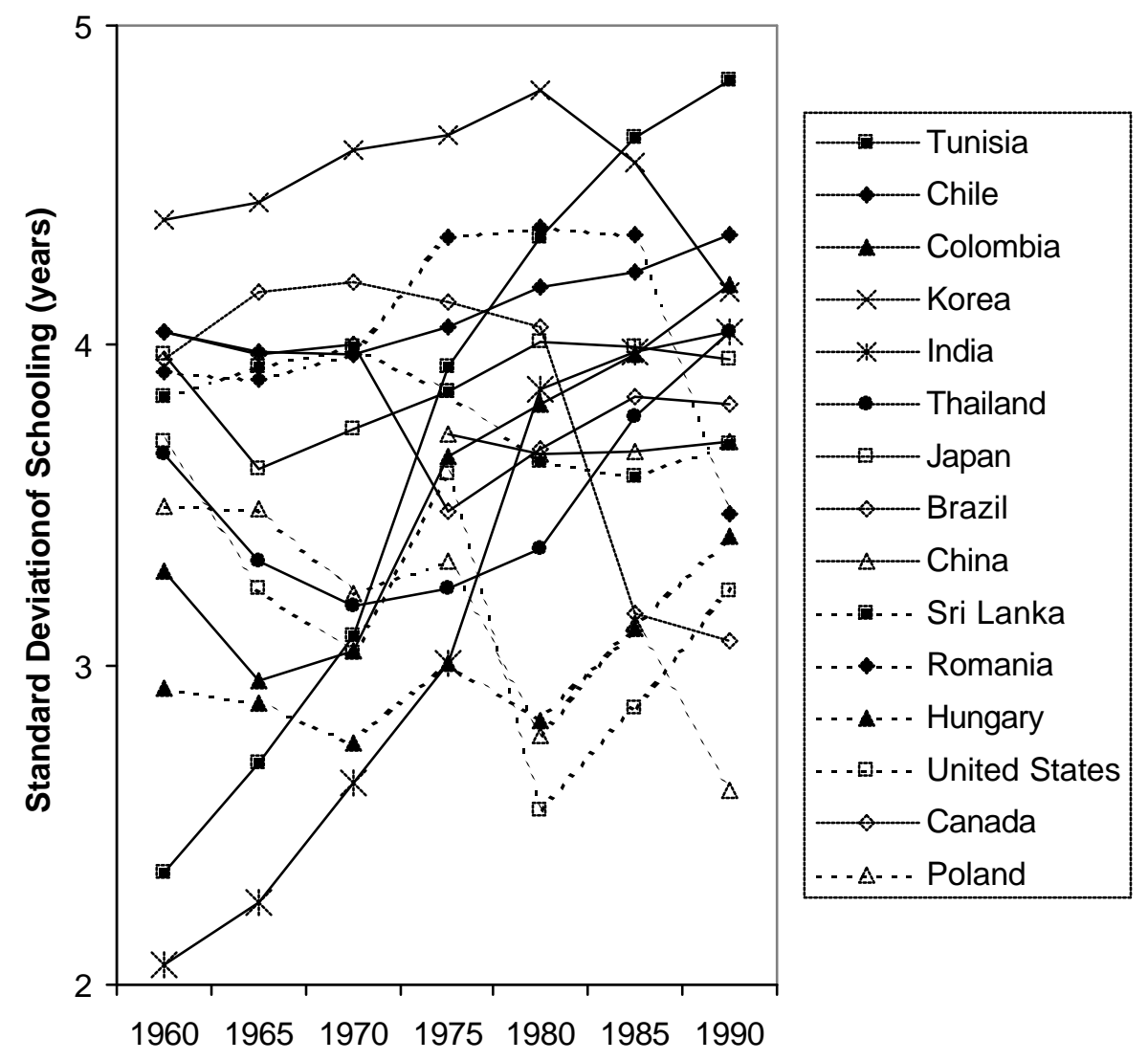

Source: Authors' calculation, data available on the web and upon request.

An interesting observation could be made after comparing the behaviors of education gini, and standard deviations in sections $4.4,4.5$ and 4.6.

- For a poor country that has a low but relatively equal school attainment (such as Tunisia), helping more people to become educated may enlarge the standard deviation of schooling. The spread of education will be widened as some people are getting higher education. The standard deviation of education would rise. But this would improve the distribution of education as measured by Education gini.

- For a country that already has a high average schooling (years $>7$ ), it would have to reduce the spread (i.e. the standard deviation) of the schooling in order to raise the average level of schooling and improve distribution.

- In both cases, education gini will decline. Therefore, education gini is a more robust and better measurement for the distribution of education. 


\subsection{Gender-Gaps and Education Inequality}

The dataset on education Gini also allows us to examine the linkage between gender inequality and education inequality. Here the gender gap is measured by the difference between female illiteracy rate and male illiteracy rate. The bigger the difference of the two illiteracy rates, the larger the gender gap. We calculated the correlation between education Gini and this special gender illiteracy gap index. And two observations can be made. First, gender gaps are positively associated with education inequality measured by gini coefficients. Second, the association between gender-gaps and education inequality had become stronger over time, as the correlation coefficients were becoming larger, from 0.53 in the 1970s to 0.69 in the 1990s (both significant) (See Figure 10).

The regression in the Table 4.3 also confirms these two points and these results are robust no matter whether we use fixed or random effect. The results imply that while educational inequality has been declining, gender inequality accounts for much of the remaining inequality in education. Reducing gender gaps in education is crucial to addressing the inequality in education.

Figure 10. Gender Gaps and Education Inequality, 1970 and 1990
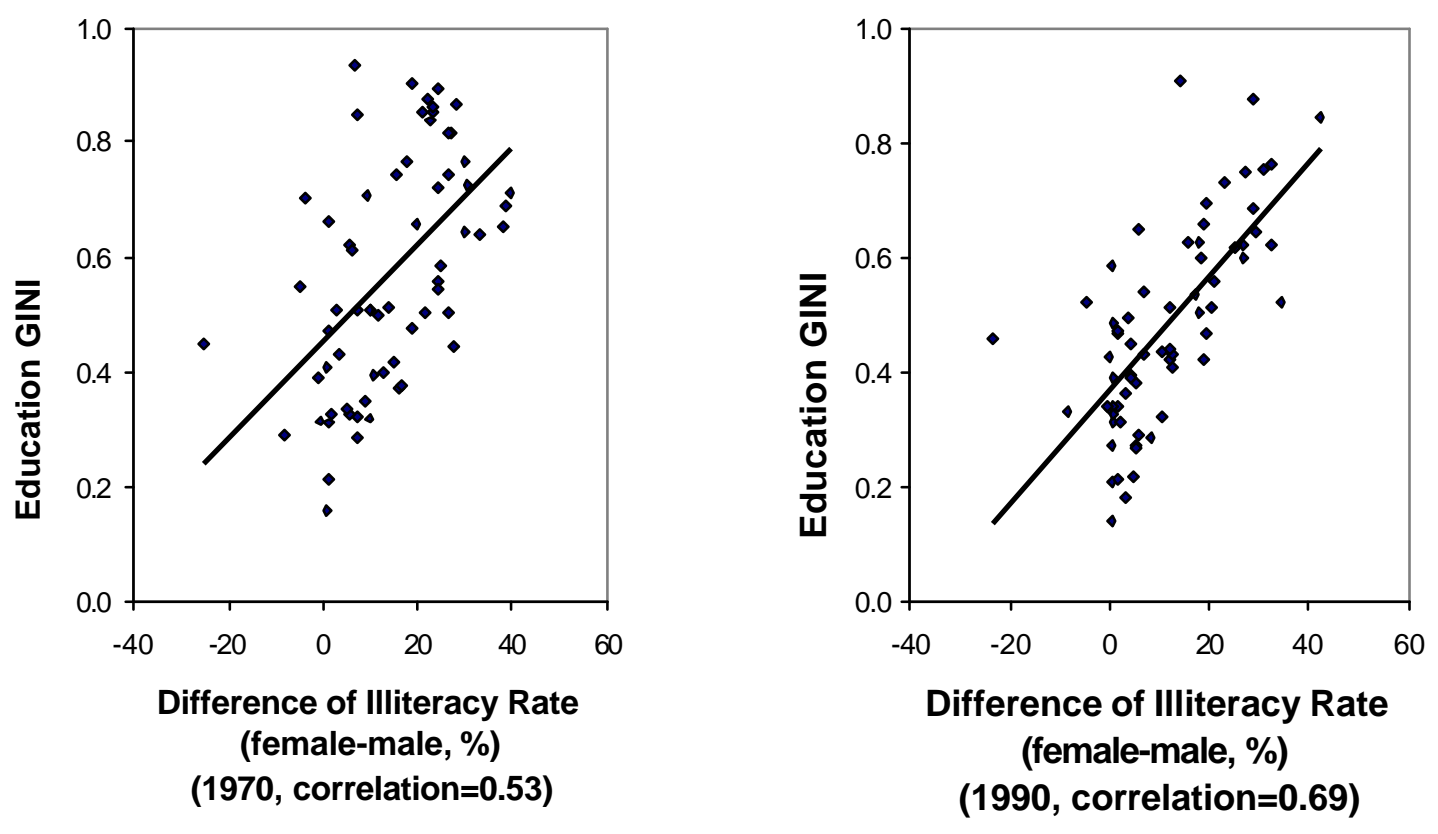

Source: education Gini: authors' calculation. Illiteracy data: World Bank central database. 


\subsection{Education Inequality and Changes in GDP Per Capita.}

While Mincerian microeconomic tests confirm a positive relation between schooling and income, the macroeconomic empirical tests on education's contribution to GDP growth have not yielded conclusive and robust results. Many have found that additional years of education per person increase real output or growth rates. But a few studies have found that human capital accumulation has an insignificant or negative impact on economic growth and productivity growth (Benhabib and Spiegel 1994; Islam 1995; Pritchett 1996). Many studies have attempted to address this puzzle including our own (López, Thomas and Wang 1999). ${ }^{8}$

López, Thomas and Wang argue that the distribution of education is important for production and growth process because education is only partially tradable. If an asset, say physical capital, is freely traded across firms in a competitive environment, its marginal product will be equalized through freemarket mechanism. If an asset is not completely tradable, however, then the marginal product of the asset across individuals is not equalized, and there is an aggregation problem. In this case, aggregate production function depends not only on the average level of the asset but also on its distribution. ${ }^{9}$ For a theoretical model incorporating the distribution of education in the production function, see López, Thomas and Wang (1999).

In addition, we suggest here that growth may not be an appropriate indicator to measure the contribution of human capital. For a high-income country, the base of the rich country's current income is so high that a increment bigger in magnitude than that of a poor country might only shows a tiny growth rate. On the contrary, for a low-income country, the base of the poor country's current income is so low that an increment smaller than that of a rich country might imply a high growth rate. In the absence of data on GDP in purchasing-power-parity (PPP) terms, growth rate became the only standard indicator for making cross-country comparisons, even though it may be misleading in many sense. We suggest that per capita PPP GDP increment is a more appropriate measure than growth rate for testing education's contribution. In the recent years, many economists have conducted painstaking work in converting the GDP data into international dollar (PPP) terms. Today, the cross-country analysis on per capita GDP increment is made feasible by the availability of the PPP GDP data.

In the scatter diagrams consisting of both the per capita PPP GDP five-year increments (in the preceding five-year period) and the education Gini, we find that there is always a downward-sloping curve for each of the four periods. The regression results shown in Table 4.4 are consistent with this point. The education inequality is negatively associated with the per capita PPP GDP increments no matter whether we use fixed or random effect. By using the PPP GDP increments in the preceding five-

\footnotetext{
${ }^{8}$ Only recently, Barro (1999b) found a clear result education attainment contributes positively to economic growth.

${ }^{9}$ Similarly as many pointed out, even capital is not perfectly tradable in an incomplete financial market where credit rationing and liquidity constraint exist, especially for the poor. That is why marginal product of capital is not equalized, and the distribution of capital or assets should enter the production function. We thank Martin Ravallion for this point. See Ravallion 1998 and 2000.
} 
year period, we have to some extent controlled for endogenuity. Similarly, there is a positive relationship between the average educational attainment and per capita PPP GDP increments (in the preceding period). The regression results are shown in Table 4.5. This positive relationship exists no matter whether we use fixed or random effect, and whether we control for time or country-specific effects.

We then regress the per capita PPP GDP increments (in the preceding five-year period) on the average education attainment and education gini, the results are mixed (Table 4.6). The coefficients for average education attainment remain positive and significant, but those for education gini become insignificant. Since we are fully convinced that our rationale of incorporating the distribution of education in the production function is correct, there could be at least two explanations. First, the theory tells us that there is an aggregation problem when marginal product of education for each individual is not equalized, and the function form for aggregation might be nonlinear. (See also Ravallion 1998, and 2000) But empirically we have only estimated a linear function. There might be a mis-specification problem. Second, there is a negative correlation between average years of education and education gini (shown in Figure 7 and Table 4.1). When putting both into one linear function, there is a multicolinearity and consequently the coefficients may have low significance levels, and they "will have the wrong sign or an implausible magnitude." (Greene 1990, p.279). ${ }^{10}$

\section{Figure 11. Education Gini, Attainment and per capita PPP GDP Increments}
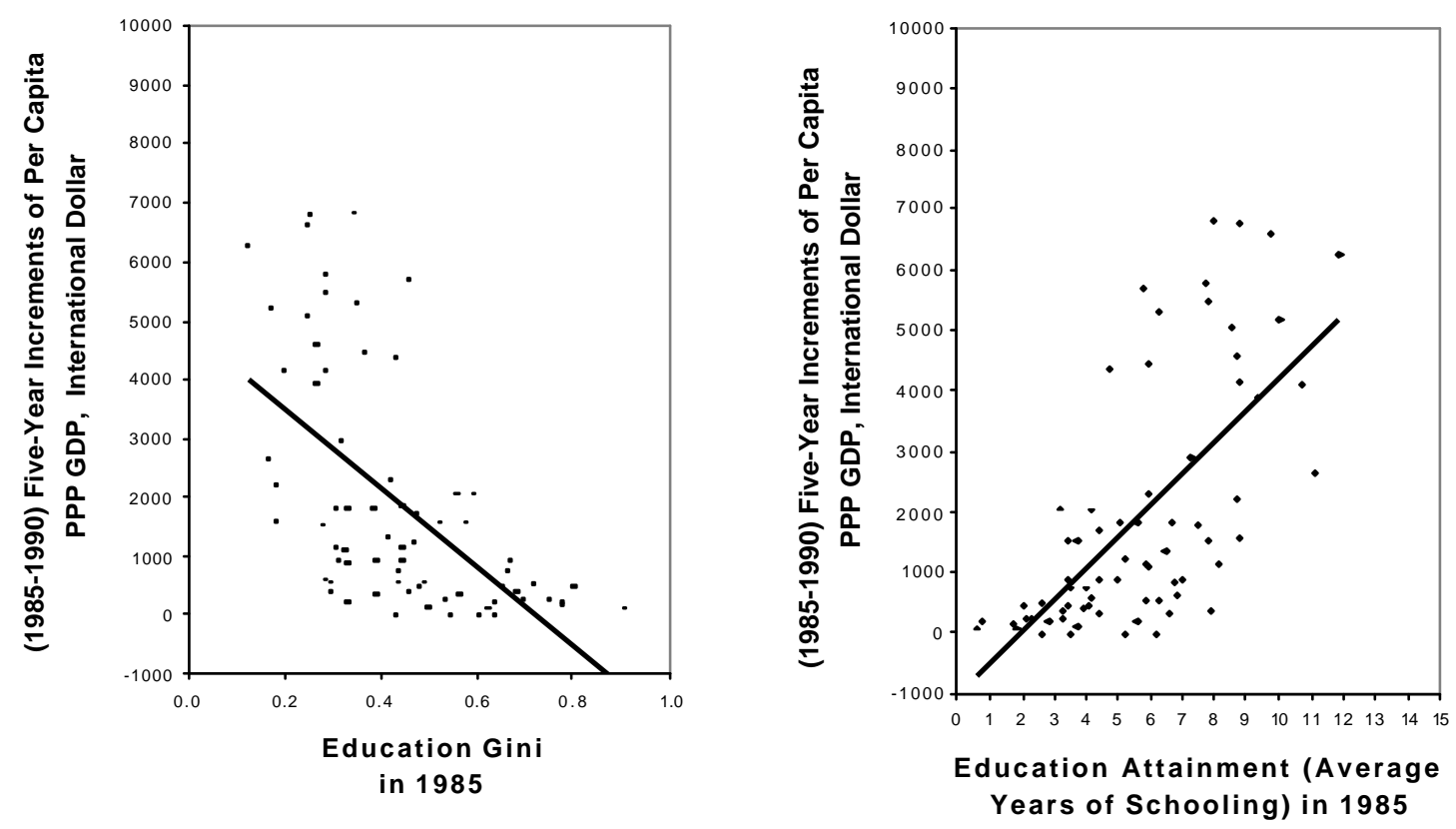

Source: education Gini: authors' calculation. GDP per capita data: World Bank central database

\footnotetext{
${ }^{10}$ This paper focuses on generating an indicator on the distribution of education as a welfare indicator. It is beyond our scope to test the causal relationship between education gini and income growth, which was attempted in Lopez, Thomas and Wang 1999 using data from 20 countries, and an interesting topic for future studies.
} 


\subsection{The Time-Space Two Dimensional Comparison: The Case of Tunisia}

We created the time-space two-dimensional diagram for education gini to allow the readers to compare one special country's education status in time-dimension against the World's education status in space-dimension, shown in Figure 12. Take the case of Tunisia as an example. ${ }^{11}$ In this diagram we can show that the education Gini and attainments for Tunisia were changing from 1960 to 1990 along the time-dimension. The education Ginis and attainments for the World were changing across various countries in space-dimension, but at the fixed time point of the year 1990.

According our data, Tunisia is among the best performers in terms of expanding the average level of education and in improving the distribution of education opportunities, as compared to the history of itself. However, Tunisia started from a position that was one of the worst. Compared to other countries, Tunisia's education attainment level was still relatively low in 1990, education inequality relatively high. But the country is on the right track: a dramatic improvement in educational opportunities has taken place, and is likely to continue, if past performance is a basis for the future. The time-space two-dimension education Gini international comparison diagram allows the readers to understand the harmony of the above seemingly contradictory claims.

Similar time-space two-dimensional comparison for other countries might look much different from that of Tunisia, with a much slower decline in education gini over time. This could provide an effective tool to show where a country stands, comparing with other countries in the world, in term of providing equal opportunities in education to its own people.

\footnotetext{
${ }^{11}$ We thank Jeffrey Waite and his colleagues for this section. It is their valuable comments and suggestions that prompt us to do some additional work on Tunisia.
} 
Figure 12 Time-Space Two-dimensional Comparison of Education Gini, Tunisia (1960-90) and World (1990)

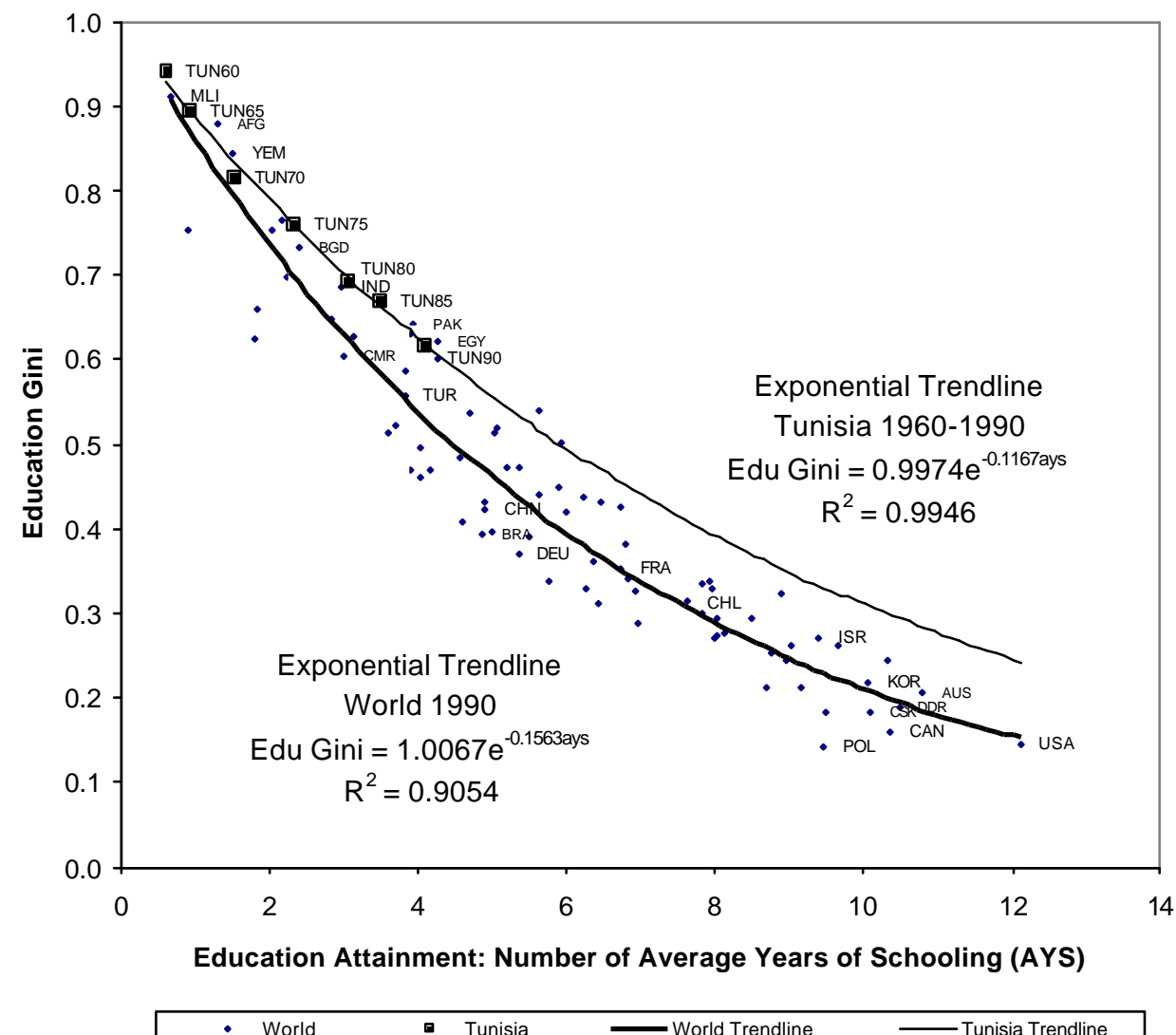

Source: education Gini and average years of schooling by authors' calculation. 


\section{Concluding Remarks}

This paper presents two methods of calculating education Gini, a direct formula and an indirect methodology of calculating education Gini though the construction of education Lorenz curve. It then generates a quinquennial dataset on education Gini, for the population age over fifteen, for 85 countries within the time span from 1960 to 1990 . In addition, this paper also calculates the data on average years of schooling and the standard deviations of schooling.

First stage empirical analysis finds that, first, inequality in education attainment for most of the countries had been declining during the three decades of 1960-1990, with a few exceptions. Second, there exists a clear pattern of inverse relationship between the education inequality measured by education Gini and the average years of schooling. This implies that the country with a higher education attainment level are most likely to achieve better education equality than the countries with lower attainment level. Data also shows that the education inequality in low-income countries was likely to be worse than that of high-income countries. Third, an education Kuznets Curve exists if the standard deviation of education is used, which is also shown in regression results. Fourth, gender-gaps are closely associated to the education inequality, and over time, the impact of gender-gaps on inequality has been stronger. Fifth, it is found that education inequality, being measured by education Gini, is negatively associated with the increments in per capita PPP GDP, after controlling for initial income levels; and that per capita PPP GDP increment is positively related to a country's level of education attainment measured by the average years of schooling.

However, we have not been able to incorporate the quality aspect into this particular gini index, which is a big challenge for the next research. We are continuing the work on education Gini along the following directions. (1) Expand the current data set to include additional countries. (2) Barro and Lee (2000) have just released their updated education data for 1960-2000, we will expand the current data set of 1960-1990 to cover 1991-2000. (3) Conduct econometric analysis to explore relationship between education inequality and other aspects of development, such as income inequality, income growth, gender gap, income level, education-related policies, and poverty.

The education gini index can be considered a new indicator for the distributional dimension of human capital and welfare, which facilitates comparison cross countries and over time. Compared with the standard deviation of schooling, education Gini is a more effective indicator that reflects the improvement in the equality of education across countries and over time. It complements the average stock and quality variables on education, not substituting them, and together they reflect a more complete picture on the educational development of a country. 


\section{Table 1.1. Selected Studies on Distributions of Education and Health/Nutrition}

\begin{tabular}{|c|c|c|}
\hline Authors & Methodology & Major Findings \\
\hline \multicolumn{3}{|c|}{ Studies used indicators of distribution of education inequality } \\
\hline $\begin{array}{l}\text { Maas and Criel } \\
(1982)\end{array}$ & $\begin{array}{l}\text { The distribution of primary school enrollment } \\
\text { was examined for Eastern African countries. } \\
\text { Gini coefficients of enrollment were estimated } \\
\text { for } 16 \text { Eastern African countries. }\end{array}$ & $\begin{array}{l}\text { 1) Enrollment Ginis varied enormously across } \\
\text { countries; and } \\
\text { 2) There is a negative link between the average } \\
\text { enrollment and its distribution--the higher the } \\
\text { average enrollment the lower the Gini coefficient. }\end{array}$ \\
\hline $\operatorname{Ram}(1990)$ & $\begin{array}{l}\text { Calculated standard deviations of education } \\
\text { for about } 100 \text { countries. }\end{array}$ & $\begin{array}{l}\text { As the average level of schooling rises, } \\
\text { educational inequality first increases, and } \\
\text { after reaching a peak, starts to decline. The } \\
\text { turning point is about seven years of } \\
\text { education. }\end{array}$ \\
\hline O'Neill (1995) & $\begin{array}{l}\text { 1. Assuming the stock of human capital is the } \\
\text { accumulation of the past education, not } \\
\text { sensitive to current income level. } \\
\text { 2. Using the variance of income and that of } \\
\text { human and physical capitals } \\
\text { 3. Using both quantities and prices of human } \\
\text { and physical capitals. }\end{array}$ & $\begin{array}{l}\text { Among the developed countries, convergence in } \\
\text { education levels has resulted in a reduction in } \\
\text { income dispersion. However, for the world as a } \\
\text { whole, incomes have diverged despite substantial } \\
\text { convergence in education levels. }\end{array}$ \\
\hline $\begin{array}{l}\text { Lopez, Thomas } \\
\& \text { Wang (1998) }\end{array}$ & $\begin{array}{l}\text { A asset allocation model is constructed, and } \\
\text { Gini coefficient of education attainment was } \\
\text { estimated for } 12 \text { countries. Used quinquennial } \\
\text { data, linkage between distribution of education } \\
\text { and growth is investigated controlling for } \\
\text { physical capital, labor and etc. }\end{array}$ & $\begin{array}{l}\text { 1. The distribution of education matters for income } \\
\text { levels as well as for growth. } \\
\text { 2. Economic reforms improved the productivity of } \\
\text { human capital in growth models. }\end{array}$ \\
\hline $\begin{array}{l}\text { Birdsall \& } \\
\text { Londono (1997) }\end{array}$ & $\begin{array}{l}\text { Cross-country analysis using a traditional } \\
\text { growth model, controlled for capital } \\
\text { accumulation, initial income and initial } \\
\text { education levels, and natural resources. }\end{array}$ & $\begin{array}{l}\text { Initial levels of educational inequality and land Gini } \\
\text { have strong negative impacts on economic growth } \\
\text { and income growth of the poorest. }\end{array}$ \\
\hline $\begin{array}{l}\text { Inter-America } \\
\text { Development } \\
\text { bank (1998) }\end{array}$ & $\begin{array}{l}\text { Regression, } \\
\text { Land Gini, income Gini, education, standard } \\
\text { deviation of education }\end{array}$ & $\begin{array}{l}\text { Income inequality (Gini) is negatively related to } \\
\text { land Gini if the Latin American counties are } \\
\text { differentiated by latitude, and positively to } \\
\text { standard deviation of education. }\end{array}$ \\
\hline $\begin{array}{l}\text { Strauss and } \\
\text { Thomas (1998) }\end{array}$ & $\begin{array}{l}\text { 1.Using both height and body mass index } \\
\text { (BMI-weight divided by height) as indicators } \\
\text { of health. } \\
\text { 2. Using wage as indicator of productivity }\end{array}$ & $\begin{array}{l}\text { Some evidence for the causal relation from income } \\
\text { to the distribution of health outcome (BMI). }\end{array}$ \\
\hline
\end{tabular}

Source: Compiled by authors. 
Table 4.1 Education attainment and education inequality

(Dependent Variable: Education Gini)

\begin{tabular}{|c|c|c|c|c|c|}
\hline & \multicolumn{2}{|c|}{$\begin{array}{c}\text { Panel regression } \\
\text { Variables stacked by date }\end{array}$} & \multicolumn{3}{|c|}{$\begin{array}{c}\text { Panel regression } \\
\text { Variables stacked by country }\end{array}$} \\
\hline Variables & Fixed effects & & Fixed effe & & Random effects \\
\hline Average years of schooling & $\begin{array}{c}-0.075 * * * * \\
(-55.45)\end{array}$ & & $\begin{array}{c}-0.051 * * * * \\
(-28.7)\end{array}$ & & $\begin{array}{c}-0.056^{* * * * *} \\
(-35.20)\end{array}$ \\
\hline Intercept(s) & Fixed effects & & Fixed effe & & $\begin{array}{l}\text { Random effects } \\
0.76^{* * * * *} \\
(66.84)\end{array}$ \\
\hline & $\begin{array}{l}\text { Year } 1960 \\
\text { Year } 1965 \\
\text { Year } 1970 \\
\text { Year } 1975 \\
\text { Year } 1980 \\
\text { Year } 1985 \\
\text { Year } 1990\end{array}$ & $\begin{array}{l}0.83 \\
0.84 \\
0.84 \\
0.85 \\
0.87 \\
0.87 \\
0.88\end{array}$ & $\begin{array}{r}\text { Algeria } \\
: \\
\text { China } \\
: \\
\text { India } \\
: \\
\text { Mexico } \\
: \\
\text { USA } \\
: \\
\text { Zambia }\end{array}$ & $\begin{array}{c}0.87 \\
: \\
0.71 \\
: \\
0.85 \\
: \\
0.72 \\
: \\
0.71 \\
: \\
0.73\end{array}$ & $\begin{array}{c}0.11 \\
: \\
-0.03 \\
: \\
0.09 \\
: \\
-0.02 \\
: \\
0.01 \\
: \\
-0.01\end{array}$ \\
\hline $\begin{array}{l}\text { Adjusted R-squared } \\
\text { Log likelihood } \\
\text { Included observations } \\
\text { Number of cross-sections } \\
\text { Total panel observations }\end{array}$ & $\begin{array}{c}0.86 \\
611.50 \\
81 \text { countries } \\
7(1960,65,70, \\
550 \text { (unbalanc }\end{array}$ & $\begin{array}{l}\text { 80,85,90) } \\
\text { panel) }\end{array}$ & $\begin{array}{r}7(1960 \\
85 \text { count } \\
583(\text { u }\end{array}$ & $\begin{array}{l}65,70,7 \\
\text { es } \\
\text { balanc }\end{array}$ & $\begin{array}{r}0.97 \\
85,90) \\
\text { anel) }\end{array}$ \\
\hline
\end{tabular}

* Significant at the 10 percent level

** Significant at the 5 percent level

*** Significant at the 1 percent level

$* * * *$ Significant at the 0.5 percent level

$\mathrm{t}$-statistics in parenthesis

Education inequality: education Gini is by authors' calculation

Education attainment: average years of schooling is by authors' calculation 


\section{Table 4.2 Education Kuznets Curve}

(Dependent Variable: Standard Deviation of Schooling)

\begin{tabular}{|c|c|c|c|c|c|}
\hline & \multicolumn{2}{|c|}{$\begin{array}{c}\text { Panel regression } \\
\text { Variables stacked by date }\end{array}$} & \multicolumn{3}{|c|}{$\begin{array}{c}\text { Panel regression } \\
\text { Variables stacked by country }\end{array}$} \\
\hline Variables & \multicolumn{2}{|c|}{ Fixed effects } & \multicolumn{2}{|c|}{ Fixed effects } & Random effects \\
\hline Average Years of Schooling & \multicolumn{2}{|l|}{$0.064 * * * *$} & \multicolumn{2}{|l|}{$0.091 * * * *$} & $\begin{array}{c}0.085 * * * * \\
(29.04)\end{array}$ \\
\hline (Average Years of Schooling) ${ }^{2}$ & \multicolumn{2}{|l|}{$\begin{array}{c}-0.048 * * * * \\
(-17.6)\end{array}$} & \multicolumn{2}{|l|}{$\begin{array}{c}-0.054 * * * * \\
(-21.53)\end{array}$} & $\begin{array}{c}-0.054 * * * * \\
(-20.96)\end{array}$ \\
\hline \multirow[t]{2}{*}{ Intercept(s) } & \multicolumn{2}{|l|}{ Fixed effects } & \multicolumn{2}{|c|}{ Fixed effects } & $\begin{array}{l}\text { Random effects } \\
1.15^{* * * *} \\
(12.40)\end{array}$ \\
\hline & $\begin{array}{l}\text { Year } 1960 \\
\text { Year } 1965 \\
\text { Year } 1970 \\
\text { Year } 1975 \\
\text { Year } 1980 \\
\text { Year } 1985 \\
\text { Year } 1990\end{array}$ & $\begin{array}{l}1.79 \\
1.83 \\
1.90 \\
2.03 \\
2.15 \\
2.23 \\
2.31\end{array}$ & $\begin{array}{r}\text { Algeria } \\
: \\
\text { China } \\
: \\
\text { India } \\
: \\
\text { Mexico } \\
: \\
\text { USA } \\
: \\
\text { Zambia }\end{array}$ & $\begin{array}{c}1.81 \\
: \\
0.86 \\
: \\
1.58 \\
: \\
1.11 \\
: \\
-0.20 \\
: \\
1.11\end{array}$ & $\begin{array}{c}0.76 \\
: \\
-0.06 \\
: \\
0.52 \\
: \\
0.19 \\
: \\
-0.80 \\
: \\
0.13\end{array}$ \\
\hline $\begin{array}{l}\text { Adjusted R-squared } \\
\text { Log likelihood } \\
\text { Included observations } \\
\text { Number of cross-sections } \\
\text { Total panel observations }\end{array}$ & $\begin{array}{c}0.55 \\
425.66 \\
81 \text { countries } \\
7(1960,65,70,7 \\
557 \text { (unbalanc }\end{array}$ & $\begin{array}{l}\text { p,85,90) } \\
\text { panel) }\end{array}$ & $\begin{array}{r}7(196 \\
85 \text { coun } \\
583 \text { (unbala }\end{array}$ & $\begin{array}{l}65,70, \\
\text { ies } \\
\text { ced pa }\end{array}$ & $\begin{array}{r}0.91 \\
85,90)\end{array}$ \\
\hline
\end{tabular}

* Significant at the 10 percent level

** Significant at the 5 percent level

$* * *$ Significant at the 1 percent level

$* * * *$ Significant at the 0.5 percent level

$\mathrm{t}$-statistics in parenthesis

Standard deviation of schooling is by authors' calculation

Education attainment: average years of schooling is by authors' calculation 
Table 4.3 Gender-Gaps are Associated with Education Inequality

(Dependent Variable: Education Gini)

\begin{tabular}{|c|c|c|c|c|c|}
\hline & \multicolumn{2}{|c|}{$\begin{array}{c}\text { Panel regression } \\
\text { Variables stacked by date }\end{array}$} & \multicolumn{3}{|c|}{$\begin{array}{c}\text { Panel regression } \\
\text { Variables stacked by country }\end{array}$} \\
\hline Variables & & \multicolumn{2}{|c|}{ Fixed effects } & Random effects \\
\hline Gender-Gap & \multicolumn{2}{|l|}{$\begin{array}{l}0.0097 * * * * \\
\quad(14.57)\end{array}$} & \multicolumn{2}{|l|}{$\begin{array}{l}0.0088 * * * * \\
\quad(9.06)\end{array}$} & $\begin{array}{l}0.091 * * * * \\
\quad(11.29)\end{array}$ \\
\hline \multirow[t]{11}{*}{ Intercept(s) } & \multicolumn{2}{|l|}{ Fixed effects } & \multicolumn{2}{|c|}{ Fixed effects } & $\begin{array}{l}\text { Random effects } \\
0.40^{* * * *} \\
(19.42)\end{array}$ \\
\hline & & & Algeria & 0.46 & 0.04 \\
\hline & Year 1970 & 0.43 & $\begin{array}{r}: \\
\text { China }\end{array}$ & $\begin{array}{c}: \\
0.46\end{array}$ & $\begin{array}{c}: \\
-0.13\end{array}$ \\
\hline & Year 1975 & 0.41 & : & : & : \\
\hline & Year 1980 & 0.39 & India & 0.49 & 0.08 \\
\hline & Year 1985 & 0.38 & : & : & : \\
\hline & \multirow[t]{5}{*}{ Year 1990} & 0.37 & Mexico & 0.40 & 0.00 \\
\hline & & & : & $:$ & : \\
\hline & & & : & $:$ & : \\
\hline & & & & : & : \\
\hline & & & Zambia & 0.32 & -0.09 \\
\hline Adjusted R-squared & \multicolumn{2}{|l|}{0.41} & & 0.95 \\
\hline Log likelihood & \multicolumn{2}{|l|}{163.56} & \multicolumn{2}{|l|}{0.94} & \\
\hline Included observations & \multicolumn{2}{|c|}{66 countries } & \multirow{2}{*}{\multicolumn{3}{|c|}{$\begin{array}{l}5(1970,75,80,85,90) \\
66 \text { countries }\end{array}$}} \\
\hline Number of cross-sections & \multicolumn{2}{|c|}{$5(1970,75,80,85,90)$} & & & \\
\hline Total panel observations & \multicolumn{2}{|c|}{ 327(unbalanced panel) } & \multicolumn{3}{|c|}{ 327(unbalanced panel) } \\
\hline
\end{tabular}

* Significant at the 10 percent level

** Significant at the 5 percent level

*** Significant at the 1 percent level

$* * * *$ Significant at the 0.5 percent level

t-statistics in parenthesis

Education inequality: education Gini is by authors' calculation

Gender-gap: difference of illiteracy rates between female and male, from World Bank central database.

Only the developing countries are included in the regression. 
Table 4.4 Education Inequality and Changes in Per Capita PPP GDP

(Dependent Variable: Per Capita PPP GDP Increments over a Five-year Interval)

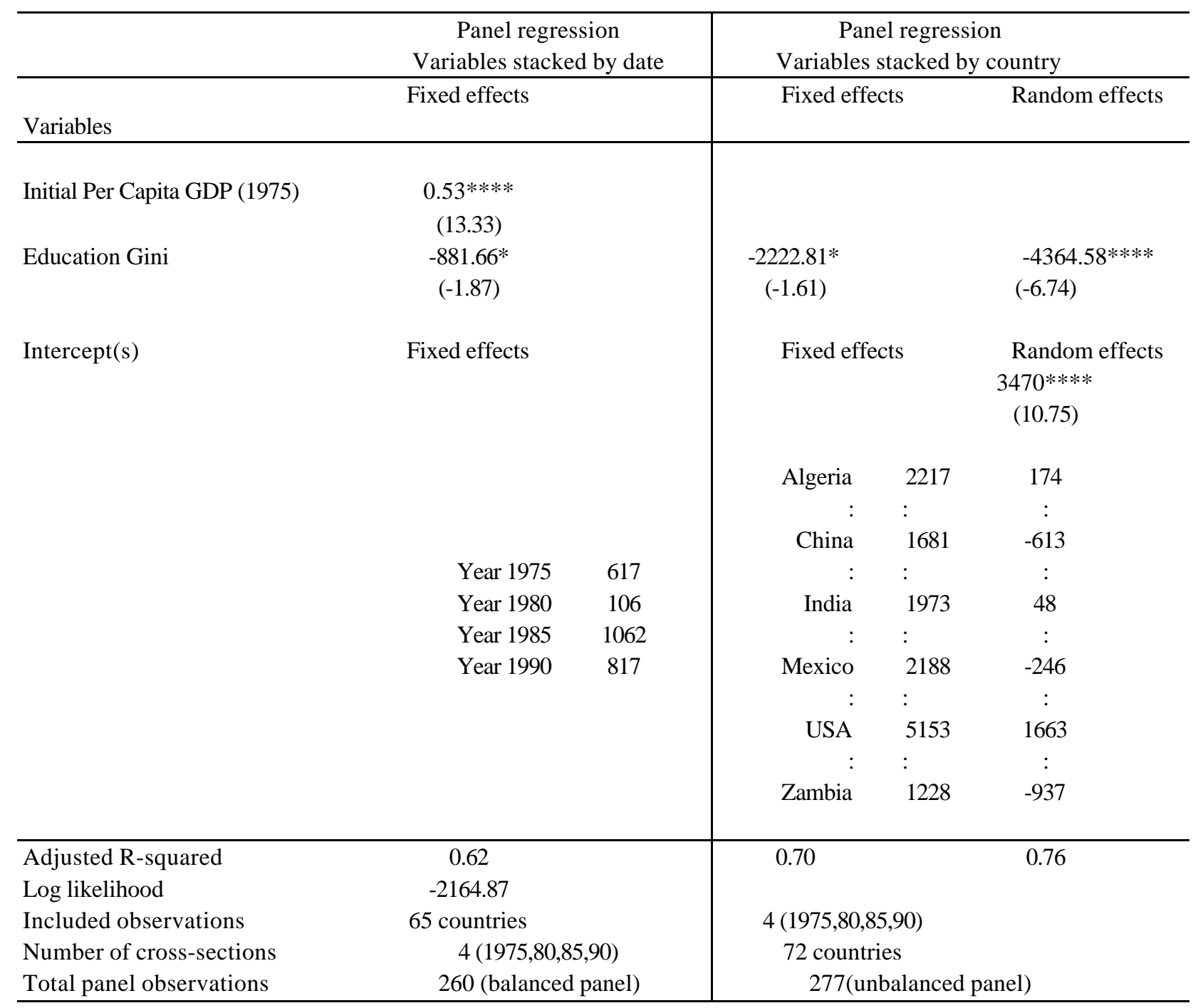

* Significant at the 10 percent level

** Significant at the 5 percent level

*** Significant at the 1 percent level

$* * * *$ Significant at the 0.5 percent level

t-statistics in parenthesis

Education inequality: education Gini is by authors' calculation

Per Capita PPP GDP is quoted from the World Bank central database.

The Per Capita PPP GDP increments over a Five-year interval are forward changes.

For example,

(1975 Five-year Increments of Per Capita PPP GDP)

= (1980 Per Capita PPP GDP) - (1975 Per Capita PPP GDP) 
Table 4.5 Education attainment and Changes in Per Capita GDP

(Dependent Variable: Per Capita PPP GDP Increments over a Five-year Interval)

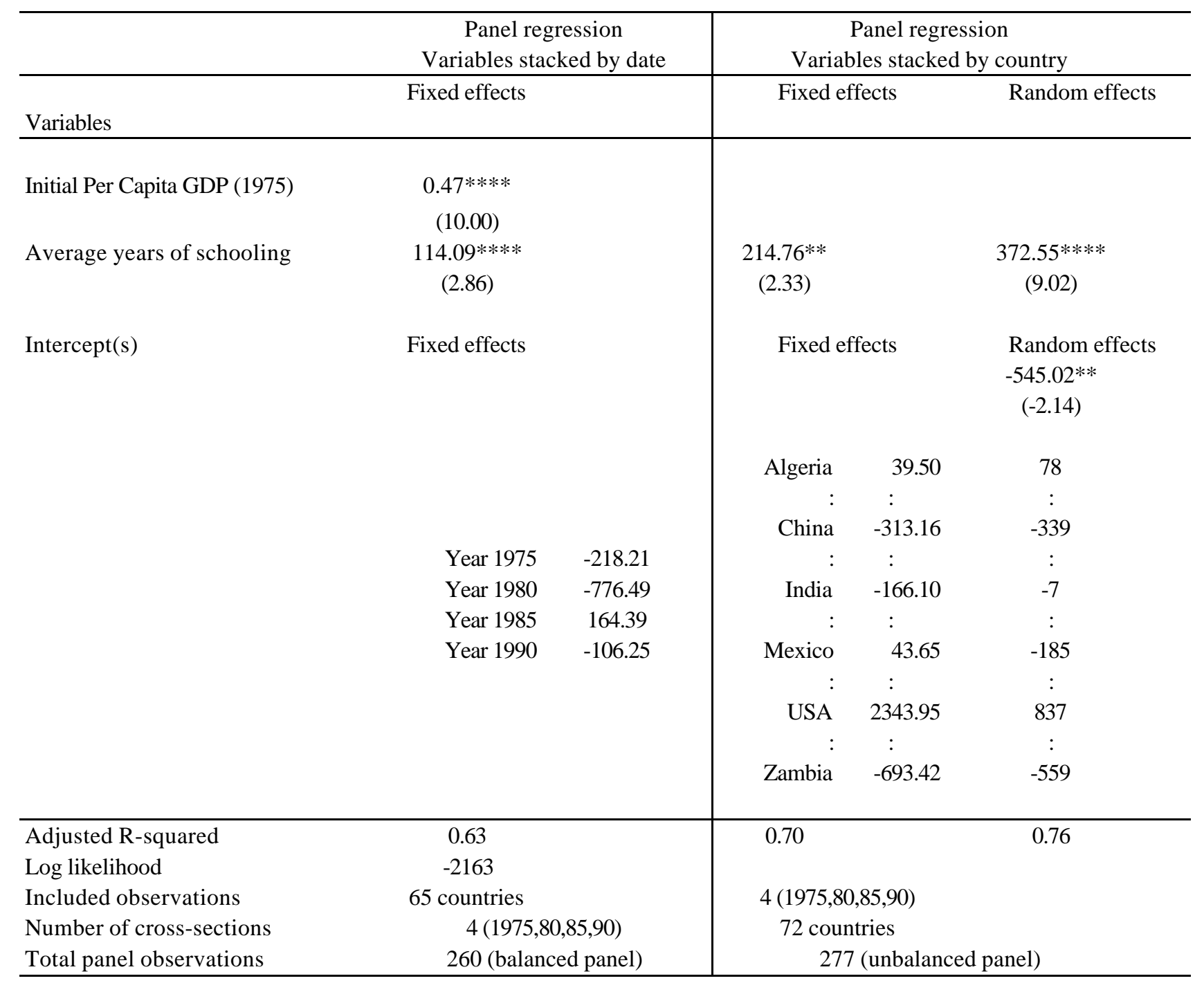

* Significant at the 10 percent level

** Significant at the 5 percent level

*** Significant at the 1 percent level

$* * * *$ Significant at the 0.5 percent level

$\mathrm{t}$-statistics in parenthesis

Education attainment: average years of schooling is by authors' calculation

Per Capita PPP GDP is quoted from the World Bank central database.

The Per Capita PPP GDP increments over a Five-year Interval are forward changes.

For example,

(1975 Five-year Increments of Per Capita PPP GDP)

= (1980 Per Capita PPP GDP) - (1975 Per Capita PPP GDP) 
Table 4.6 Education attainment, education inequality, and changes in per capita GDP

(Dependent Variable: Per Capita PPP GDP Increments over a Five-year Interval)

\begin{tabular}{|c|c|c|c|c|c|}
\hline \multirow[b]{2}{*}{ Variables } & \multicolumn{2}{|c|}{$\begin{array}{c}\text { Panel regression } \\
\text { Variables stacked by date }\end{array}$} & \multicolumn{3}{|c|}{$\begin{array}{c}\text { Panel regression } \\
\text { Variables stacked by country }\end{array}$} \\
\hline & \multicolumn{2}{|l|}{ Fixed effects } & \multicolumn{2}{|c|}{ Fixed effects } & Random effects \\
\hline Initial Per Capita GDP (1975) & \multicolumn{2}{|l|}{$\begin{array}{l}0.46 * * * * \\
(9.51)\end{array}$} & & & \\
\hline Average years of schooling & \multicolumn{2}{|l|}{$\begin{array}{l}189.12 * * \\
(2.42)\end{array}$} & $\begin{array}{c}303.84 * \\
(1.78)\end{array}$ & & $\begin{array}{c}512.43 * * * * \\
(5.07)\end{array}$ \\
\hline Education Gini & \multicolumn{2}{|l|}{$\begin{array}{c}1022.32 \\
(1.12)\end{array}$} & \multicolumn{2}{|l|}{$\begin{array}{c}1571.57 \\
(0.62)\end{array}$} & $\begin{array}{c}2149.22 \\
(1.50)\end{array}$ \\
\hline \multirow[t]{11}{*}{ Intercept(s) } & \multirow{3}{*}{\multicolumn{2}{|c|}{ Fixed effects }} & \multicolumn{2}{|c|}{ Fixed effects } & $\begin{array}{l}\text { Random effects } \\
-2283.9^{*} \\
(-1.93)\end{array}$ \\
\hline & & & Algeria & -1306 & -47 \\
\hline & & & China & $\begin{array}{c}: \\
-1462\end{array}$ & $\begin{array}{c}: \\
-263\end{array}$ \\
\hline & Year 1975 & -1044 & : & : & : \\
\hline & Year 1980 & -1619 & India & -1525 & -135 \\
\hline & Year 1985 & -682 & : & : & : \\
\hline & \multirow[t]{5}{*}{ Year 1990} & -962 & Mexico & -1146 & -169 \\
\hline & & & : & : & : \\
\hline & & & USA & 1089 & 682 \\
\hline & & & : & : & $:$ \\
\hline & & & Zambia & -1832 & -461 \\
\hline Adjusted R-squared & \multicolumn{2}{|l|}{0.63} & \multicolumn{2}{|l|}{0.70} & 0.76 \\
\hline Log likelihood & \multicolumn{2}{|l|}{-2162} & & & \\
\hline Included observations & \multicolumn{2}{|l|}{65 countries } & \multicolumn{2}{|c|}{$4(1975,80,85,90)$} & \\
\hline Number of cross-sections & \multicolumn{2}{|c|}{$4(1975,80,85,90)$} & \multicolumn{2}{|c|}{72 countries } & \\
\hline Total panel observations & \multicolumn{2}{|c|}{260 (balanced panel) } & \multicolumn{3}{|c|}{277 (unbalanced panel) } \\
\hline
\end{tabular}

* Significant at the 10 percent level

** Significant at the 5 percent level

$* * *$ Significant at the 1 percent level

$* * * *$ Significant at the 0.5 percent level

$\mathrm{t}$-statistics in parenthesis

Education attainment: average years of schooling is by authors' calculation

Education inequality: education Gini is by authors' calculation

Per capita PPP GDP is quoted from the World Bank central database.

The Per Capita PPP GDP increments over a five-year interval are forward changes.

For example,

(1975 Five-year Increment of Per Capita PPP GDP)

= (1980 Per Capita PPP GDP) - (1975 Per Capita PPP GDP) 


\section{References}

Anand, Sudhir; and Kanbur, S. M. R. 1993. "The Kuznets Process and the Inequality-Development Relationship." Journal of Development Economics; v40, n1, February 1993, pp. 25-52.

Arneson, Richard. 1989. "Equity and Equality of Opportunity for Welfare." Philosophical Study 56: 7793.

Atkinson, A. B.; Rainwater, L.; and Smeeding, T. 1995. "Income Distribution in European Countries." University of Cambridge, Department of Applied Economics Working Paper, Amalgamated Series: 9535 November 1995, pp. 36.

Barro, Robert J. 1991. "Economic Growth in a Cross Section of Countries." Quarterly Journal of Economic; 106 (May 91): 407-443.

Barro, Robert J. 1996. "Determinants of Economic Growth: A Cross-Country Empirical Study." National Bureau of Economic Research Working Paper: 5698, August 96, pp. 71.

Barro, Robert J. 1999a. "Inequality, Growth, and Investment." National Bureau of Economic Research Working Paper: 7038, March 1999, pp. 71.

Barro, Robert J. 1999b. "Inequality and Growth in a Panel of Countries." National Science Foundation, available on the web.

Barro, Robert J.; and Lee, J. W. 1993. "International Comparisons of Educational Attainment." Journal of Monetary Economics; 32, no.3 (December 93). 363-394.

Barro, Robert J.; and Lee, J. W.. 1997. "International Measures of Schooling Years and Schooling Quality." American Economic Review; Papers and Proceedings, 86(2), pp. 218-223.

Barro, Robert J.; and Lee, J. W. 2000. "International Data on Educational Attainment: Updates and Implications." CID working paper no. 42, Center for International Development at Harvard University, April and August.

Behrman, Jere. 1987. "Schooling in developing countries: Which countries are the over and underachievers and what is schooling impact?" Economics of Education Review; 6(2):111-127.

Behrman, Jere; and Birdsall, Nancy. 1983. "The Quality of Schooling. Quantity Alone Is Misleading." American Economic Review; 73(5):928-946.

Bhagwati, Jagdish. 1973. "Education, Class Structure, and Income Inequality." World Development 1(5):21-36.

Birdsall, Nancy and Londoño, Juan Luis. 1997. “Asset Inequality Matters: An Assessment of the World Bank’s Approach to Poverty Reduction.” American Economic Review 87(2): 32-37.

Bonilla-Chacin, Maria. And Jeffrey Hammer. 1999. "Life and Death among the Poorest." Paper presented at the World Bank Economist Forum, May 3-4, Washington, DC.

British Council. Various Years. Education Profile.

Chong, Albert; and Cesar Calderón. 1997. "Empirical tests on Causality and feedback between Institutional Measures and Economic Growth.” Mimeograph. Washington, DC: World Bank.

Cohen, G. A. 1989. "On the Currency of Egalitarian Justice.” Ethics 99: 906-944.

Dahan, Momi. 1996. "The Effect of Macroeconomic Variables on Income Distribution in Israel." Bank of Israel Economic Review;v0, n69, March 1996, pp. 19-43.

Dasgupta, Partha. 1990. "Well-being and the Extent of its Realization in Developing Countries." Economic Journal 100(4, supplement):1-32.

Deaton, Angus. 1997. The Analysis of Household Surveys: A Microeconomic Approach to Development Policy. Johns Hopkins University Press, Baltimore and London.

Deininger, Klaus; and Squire, Lyn. 1996. "A New Dataset Measuring Income Inequality.” World Bank Economic Review; 10(3), September 565-91. 
Deininger, Klaus; and Squire, Lyn. 1998. "New Ways of Looking at Old Issues: Inequality and Growth." Journal of Development Economics; v57, n2, December 1998, pp. 259-87.

Dubey, Ashutosh, and Elizabeth M. King. 1996. " A New Cross-Country Education Stock Series Differentiated by Age and Sex." Journal of Educational Planning and Administration 11(1): 5-24.

Dworkin, Ronald. 1981. "What is Equity: Part 2. Equality of Resources." Philos. \& Public Affairs; 81, 10. pp. 283-345.

Easterly, William. 1999. "Life during Growth.” Journal of Economic Growth 4(3): 239-79.

Fan, Xibo. 2000. "The Formula for Calculating Education Gini Index." Working paper, The World Bank Institute, Washington, DC.

Fields, Gary. 1980. Poverty, Inequality, and Development. Cambridge: Cambridge University Press.

Galor, Oded; and Zeira, J. 1993. "Income Distribution and Macroeconomics." Review of Economic Studies; LX: 35-52.

Galor, Oded; and Tsiddon, Daniel. 1996. "Income Distribution and Growth: The Kuznets Hypothesis Revisited." Economica; v63, n250, Supplementary, 1996, pp. S103-17.

Glomm, Gerhard. 1997. "Whatever Happened to the Kuznets Curve? Is It Really Upside Down?" Journal of Income Distribution; v7, n1, 1997, pp. 63-87.

Greene, William H. 1990. Econometric Analysis. MacMillan Publishing Company, New York.

Haddad, Lawrence; and Kanbur, Ravi. 1992. "Is There an Intrahousehold Kuznets Curve? Some Evidence from the Philippines." Public Finance; v47, n0, Supplementary, 1992, pp. 77-93.

Hanushek, Eric A.; and Kim, Dongwook. 1995. "Schooling, Labor Force Quality, and Economic Growth." National Bureau Of Economic Research paper 5399.

Inter-American Development Bank. 1999. Facing up to Inequality in Latin America: Economic and Social Progress in Latin America, 1998-99 Report. Johns Hopkins University Press.

Kaneko, M. 1986. "The Education Composition of the World Population.” Education and Training Report, World Bank. Washington, DC. April 86.

Komen, Marinus H. C.; Gerking, Shelby; Folmer, Henk. 1997. "Income and Environmental R\&D: Empirical Evidence from OECD Countries." Environment and Development Economics; v2, n4, October 1997, pp. 505-15.

Kuznets, Simon. 1955. "Economic Growth and Income Inequality." American Economic Review; March 1955, pp 1-28.

Kuznets, Simon. 1963. "Quantitative Aspects of the Economic Growth of Nations: VIII, Distribution of Income by Size." Economic Development and Cultural Change; January 1963, pt.2, pp. 1-80.

Kuznets, Simon. 1966. Modern Economic Growth. New Haven: Yale University Press.

Kuznets, Simon. 1976. "Demographic Aspects of the Size Distribution of Income." Economic Development and Cultural Change; October 1976, pp. 1-94.

Lam, David and Deborah Levison. 1991. "Declining Inequality in Schooling in Brazil and its Effects on Inequality in Earnings." Journal of Development Economics 37(1-2): 199-225.

Lanjouw, Peter and Nicholas Stern. 1998. Economic Development in Palanpur Over Five Decades. New York: Oxford University Press.

Lee, Jong-Wha; and Barro, Robert J. 1997. "Schooling Quality in a Cross Section of Countries." Working paper no. 6198. National Bureau of Economic Research, Cambridge, MA.

Levine, Ross; and Renelt, David. 1992. "A sensitive analysis of cross country growth regression." American Economic Review; 82 (Sept. 1992). No.4. 942-63

Levine, Ross; and Zervos, Sara J. 1993. "What we have learned about policy and growth from crosscountry regressions?" American Economic Review; 83. May 1993. No.2 426-30.

Li, Hongyi; Squire, Lyn; and Zou, Heng-fu. 1998. "Explaining International and Intertemporal Variations in Income Inequality.” Economic Journal; 108:26-43. 
Lockheed, E. Marlaine, and Adriaan M. Verspoor. 1991. Improving Primary Education in Developing Countries. New York: Oxford University Press.

López, Ramón; Thomas, Vinod; and Wang, Yan. 1998. "Addressing the Education Puzzle: The Distribution of Education and Economic Reform." Policy Research Working Paper \#2031. The World Bank, Washington, D.C.

Londoño, Juan Luis, 1990. 'Kuznetsian Tales with Attention to Human Capital." Paper presented at the Third Inter-American Seminar in Economics, Rio de Janeiro, Brazil.

Lundberg, Mattias; and Squire, Lyn. 1999. "Growth and Inequality: Extracting the Lessons for PolicyMakers." Unpublished. The World Bank, Washington, D.C.

Maas, Jacob van Lutsenburg, and Ceert Criel. 1982. Distribution of Primary School Enrollments in Eastern Africa. World Bank Staff Working Papers no.511. The World Bank, Washington DC.

Mankiw, N. Gregory; Romer, David; and Weil, David. 1992. "A contribution to the empirics of economic growth." Quarterly Journal of Economics; (May 1992). 407-37.

Nehru, Vikram; Swanson, Eric; and Dubey, Ashutosh. 1995. "A new database on human capital stock: sources, methodology and results." Journal of Development Economics; v46, n2, April 1995, pp. 379-401.

Ogwang, Tomson. 1995. "The Economic Development-Income Inequality Nexus: Further Evidence on Kuznets' U-Curve Hypothesis.” American Journal of Economics and Sociology; v54, n2, April 1995, pp. 217-29.

O’Neill, Donal. 1995. "Education and Income Growth: Implications for Cross-Country Inequality." Journal of Political Economy 103(6): 1289-1301.

Park, Walter G.; Brat, David A. 1995. “A Global Kuznets Curve?” Kyklos; v48, n1, 1995, pp. 105-31.

Prichett, Lant. 1997. "Where has All the Education Gone?" World Bank Working Paper 1581. World Bank, Washington, DC.

Psacharopoulos, G. 1984. " The Contribution of Education to Economic Growth: International Comparisons.” In J.W. Kendrick (ed.) International Comparisons of Productivity and Causes of the Slowdown. Cambridge, Mass: Ballinger Publishing Co.

Psacharopoulos, G.; Tan, J. P.; and Jimenez, E. 1986. Financing Education in Developing Countries: An Exploration of Policy Options. Washington, D.C: World Bank.

Psacharopoulos, George; and Arriagada, Ana-Maria. 1986. "The educational attainment of the labor force: an international comparison.” The World Bank, October 86. Report No.: EDT38.

Quan, Nguyen T.; and Koo, Anthony Y. C. "Concentration of Land Holdings: An Empirical Exploration of Kuznets' Conjecture.” Journal of Development Economics; v18, n1, May-June 1985, pp. 10117.

Ram, Rati. 1988. "Economic Development and Income Inequality: Further Evidence on the U-Curve Hypothesis." World Development, v16, n11, November 1988, pp. 1371-76.

Ram, Rati. 1989. "Level of Development and Income Inequality: An Extension of Kuznets-Hypothesis to the World Economy." Kyklos; v42, n1, 1989, pp. 73-88.

Ram, Rati. 1990. "Educational Expansion and Schooling Inequality: international edidence and some implications". The Review of Economics and Statistics; 72(2), 1990, pp.266-74.

Ram, Rati. 1991."Kuznes's Inverted-U Hypothesis: Evidence from a Highly Developed Country." Southern Economic Journal; v57, n4, April 1991, pp. 1112-23.

Ram, Rati. 1992. "Intercountry Inequalities in Income and Basic-Needs Indicators: A Recent Perspective." World Development, v20, n6, June 1992, pp. 899-905.

Ram, Rati. 1997. "Level of Economic Development and Income Inequality: Evidence from the Postwar Developed World.” Southern Economic Journal; v64, n2, October 1997, pp. 576-83.

Ram, Rati. 1997. "Reply to the Comment on Rati Ram's Test of the Kuznets Hypothesis." Economic Development and Cultural Change; v46, n1, October 1997, pp. 191-95. 
Ravallion, Martin. 1997. "A Comment on Rati Ram's Test of the Kuznets Hypothesis." Economic Development and Cultural Change; v46, n1, October 1997, pp. 187-90.

Ravallion, Martin. 1998. "Does the Aggregation hide the harmful effects of inequality on growth?" Economics Letters 61(1998): 73-77.

Ravallion, Martin. 2000. "Growth, Inequality and Poverty: Looking Beyond Averages.” Working paper, Development Research Group, The World Bank, Washington, DC.

Ravallion, Martin, and Gaurav Datt. 1999. "When is Growth pro-poor? Evidence from the Diverse Experiences of India's States." Policy Research Working papers no. 2263. World Bank, Development Research Group. Washington, DC.

Roemer, John E. 1993. "A Pragmatic Theory of Responsibility for the Egalitarian Planner." Philosophy and Public Affairs 22: 146-66.

Rosthal, Richard A. 1978. "Measures of Disparity. A Note." Research report published by Killalea Associates, Inc. Available at EDRS Price, ED149482, ERIC database.

Sen, Amartya K. 1980. "Equality of What?" In S. McMurrin, ed., Tanner Lectures on Human Values, vol I. Cambridge, U.K.: Cambridge University Press.

Sheret, Michael. 1988. "Equality Trends and Comparisons for the Education System of Papua New Guinea." Studies in Educational Evaluation, v.14 (1):91-112.

Strauss, John and Duncan Thomas. 1998. "Health, Nutrition and Economic Development", Journal of Economic Literature, Vol XXXVI (June 1998):766-817.

Thomas, Vinod et al. 2000. The Quality of Growth. New York: Oxford University Press.

UNESCO. Various years. Statistical Yearbook. Paris.

Williamson, Jeffrey G. 1998. "Growth, Distribution, and Demography: Some Lessons from History." Explorations in Economic History; v35, n3, July 1998, pp. 241-71.

World Bank. 1999. Education Sector Strategy. Washington, DC.

World Bank. 2000a. Engendering Development. New York: Oxford University Press.

World Bank. 2000b. Attacking Poverty. The World Development Report 2000/01. New York: Oxford University Press. 